\title{
How have both cultivation and warming influenced annual global isoprene and monoterpene emissions since the preindustrial era?
}

\author{
K. Tanaka ${ }^{1}$, H.-J. Kim ${ }^{1}$, K. Saito ${ }^{1}$, H. G. Takahashi ${ }^{1,2}$, M. Watanabe ${ }^{3}$, T. Yokohata ${ }^{4}$, M. Kimoto ${ }^{3}$, K. Takata ${ }^{1,5}$, and \\ T. Yasunari ${ }^{1,6}$ \\ ${ }^{1}$ Research Institute for Global Change, Japan Agency for Marine-Earth Science and Technology, Yokohama, Japan \\ ${ }^{2}$ Department of Geography, Tokyo Metropolitan University, Hachioji, Japan \\ ${ }^{3}$ Atmospheric and Ocean Research Institute, The University of Tokyo, Kashiwa, Japan \\ ${ }^{4}$ National Institute for Environmental Studies, Tsukuba, Japan \\ ${ }^{5}$ National Institute of Polar Research, Tokyo, Japan \\ ${ }^{6}$ Hydrospheric Atmospheric Research Center, Nagoya University, Nagoya, Japan
}

Correspondence to: K. Tanaka (ktanaka@jamstec.go.jp)

Received: 21 May 2012 - Published in Atmos. Chem. Phys. Discuss.: 5 July 2012

Revised: 19 September 2012 - Accepted: 2 October 2012 - Published: 25 October 2012

\begin{abstract}
To examine the influence of both crop cultivation and surface air temperatures (SATs) on annual global isoprene and monoterpene emissions, which can lead to the formation of secondary organic aerosols (SOAs), we simulated, on a monthly basis, the annual emissions of volatile organic compounds (VOCs) during the period 1854-2000. The model estimates were based on historical climate data such as SATs, and downward solar radiation (DSR) reproduced with an atmospheric-ocean circulation model, as well as a time series of the global distribution of cropland (to test the hypothesis that conversion of forests into croplands lowers emissions). The simulations demonstrated that global SAT, DSR, the combination of SAT and DSR, and the expansion of cropland all affected emissions. The effect of cropland expansion (i.e., forest conversion) on annual emissions during this period was larger for isoprene ( $\sim 7 \%$ reduction on a global scale) than for monoterpenes $(\sim 2 \%$ reduction), mainly because of the reduction in broadleaf evergreen forests (BEFs) in Southeast Asia, which have the highest and most constant emissions of isoprene and where both temperature and radiation are high all year round. The reduction in the Amazon region and in parts of Africa, which are other primary sources of annual global isoprene emissions, but where the conversion of BEF to cropland has been much smaller than in Southeast Asia, was less remarkable, probably because the broadleaf deciduous forests and $\mathrm{C} 4$ grasslands in these areas have lower and seasonal emissions;
\end{abstract}

hence, their conversion has less effect. On the other hand, the difference in the emission factors $(\varepsilon)$ between cropland and the other vegetation types was much lower for monoterpenes than for isoprene, although the $\varepsilon$ for cropland was generally the lowest for both compounds. Thus, the expansion of cropland also contributed to the reduction in monoterpene emissions to some degree, but had less effect. A 5\% increase in emissions due to rising SAT was more than offset by the decrease in isoprene emissions and a concurrent $\sim 2 \%$ reduction caused by a decrease in DSR. Overall, annual global isoprene emissions in 2000 were lower than in 1854 by $13 \mathrm{TgC} \mathrm{yr}^{-1}$, whereas annual global monoterpene emissions were higher by $2.3{\mathrm{TgC} \mathrm{yr}^{-1}}^{-}$.

\section{Introduction}

Monoterpene secondary organic aerosols (SOAs) are the most important organic aerosol components on a global scale (Chung and Seinfeld, 2002; Engelhart et al., 2008). SOAs act as cloud condensation nuclei (Novakov and Penner, 1993) and directly scatter or absorb solar radiation (Andreae and Crutzen, 1997; Chung and Seinfeld, 2002). The photooxidation of isoprene generates SOAs (Jang et al., 2002). However, previous estimates of isoprene-related SOA levels are being reconsidered (Claeys et al., 2004; Henze and Seinfeld, 2006; Paulot et al., 2009), as an organic aerosol that 
has been found in several forested areas is strongly indicative of an isoprene precursor (Matsunaga et al., 2003; Ion et al., 2005; Kourtchev et al., 2005). Vegetation is thought to contribute to about $90 \%$ of global emissions of volatile organic compounds (VOCs) (Kuhn et al., 2004), and Guenther et al. (1995) estimated that the annual global VOC flux is $1150 \mathrm{TgC}$, composed of $44 \%$ isoprene, $11 \%$ monoterpenes, $22.5 \%$ other reactive VOCs, and $22.5 \%$ other VOCs. That study also showed that the contribution to VOCs from vegetation should not be ignored when considering carbon cycles. The estimation of VOC emissions from vegetation, especially isoprene and monoterpene emissions, is essential for understanding global tropospheric chemistry and regional photochemical oxidant formation, for balancing the global carbon cycle, and for understanding the production of organic acids (Fehsenfeld et al., 1992).

Vegetation is influenced by climate changes, and much vegetation has been rapidly replaced with croplands since the preindustrial era (Ramankutty and Foley, 1999; Hurtt et al., 2006). Global warming has occurred over the past $150 \mathrm{yr}$; for example, Folland et al. (2001) reported that annual global surface temperature increased by $0.61 \pm 0.16^{\circ} \mathrm{C}$ between 1861 and 2000, based on SAT data. Because isoprene and monoterpene emissions increase with temperature (e.g., Guenther et al., 1993), the warming likely accelerates emissions on a global scale. At higher temperatures, the woody parts of vegetation are more likely to release diverse mixtures of terpenoids, including both isoprene and monoterpenes (Owen et al., 2001; Keeling and Bohlmann, 2006). Grasses and cereals are not generally major isoprene emitters, although they emit oxygenated biogenic VOCs (BVOCs) (König et al., 1995; Kirstine et al., 1998; Davison et al., 2008). Hence, the conversion of forested areas to cropland is predicted to decrease BVOC emissions in certain geographical areas (Laothawornkitkul et al., 2009). The two effects offset each other, and the changes in VOC emissions likely depend on the balance between vegetation type, crop type, temperature, and region. Thus, the observed changes in global VOC emissions may have influenced spatial and temporal SOA composition since the preindustrial era (1850s) (Tsigaridis et al., 2006).

Lathière et al. (2005) estimated global annual isoprene and monoterpene emissions from the terrestrial biosphere between the preindustrial era and present day, using static mode simulation; annual values were found to be $409 \mathrm{TgC}$ and $127 \mathrm{TgC}$ for the preindustrial era, and $402 \mathrm{TgC}$ and $131 \mathrm{TgC}$ for the present day, respectively. Lathière et al. (2010) also estimated global annual isoprene emissions from the terrestrial biosphere during the 20th century with a dynamic vegetation model that considered the negative effect of an increase in leaf area under rising atmospheric $\mathrm{CO}_{2}$, and found that anthropogenic cropland expansion contributed the most $(15 \%)$ to the reduction in isoprene emissions that occurred by 2002 , while climate changes and rising $\mathrm{CO}_{2}$ caused a $7 \%$ increase and a $21 \%$ reduction, respectively. Thus, the au- thors estimated that the present day annual global isoprene emissions would decrease and that monoterpene emissions would increase in the current era compared to the preindustrial era and to the early 20th century, and they demonstrated the influences of climate change and cropland expansion on both types of emissions (Lathière et al., 2005). The authors also demonstrated the influence of ambient $\mathrm{CO}_{2}$ on isoprene emissions (Lathière et al., 2010).

In the present study, we estimated the annual global isoprene and monoterpene emissions from the preindustrial era to the present. We used the Model of Emissions of Gases and Aerosols from Nature (MEGAN) (Guenther et al., 2006), which is based on historical climate data reproduced with the atmospheric-ocean circulation Model for Interdisciplinary Research on Climate (MIROC5), version 5 (Watanabe et al., 2010), and the expansion of cropland since the preindustrial era (Hurtt et al., 2006). We focused on how the expansion of cropland, and climate factors such as air temperature and solar radiation, influenced the annual global isoprene and monoterpene emissions from the preindustrial era to the present. Simulations also considered historical emissions from areas including and excluding large expansions of cropland and how each vegetation type in each area contributed to both annual emissions from 1854 to 2000 .

\section{Materials and methods}

To estimate emissions for isoprene and monoterpenes (classified by eight components: myrcene, sabinene, limonene, 3 -carene, ocimene, $\beta$-pinene, $\alpha$-pinene, and other monoterpenes), we used the MEGAN model (Guenther et al., 2006) and monthly climatic data including ambient solar radiation and air temperature at $2 \mathrm{~m}$ above the land surface (Watanabe et al., 2011). The climatic data were reproduced by a historical run from 1850 to 2005 with MIROC5 (Watanabe et al., 2010), which is an atmospheric ocean circulation model with the standard resolution of the T85 $(256 \times 128$ regular longitude/latitude global horizontal grid; approximately 1.4degree resolution) atmosphere and one-degree ocean models. The model considered historical solar irradiance data (Lean et al., 2005) and surface aerosols emission data, and it reproduced the observed global mean surface air temperature during the 20th century well (Watanabe et al., 2011). The expansion of cropland is described as the ratio of cropland to each grid (Hurtt et al., 2006). The global distribution of potential vegetation types shown by Ramankutty and Foley (1999) was consulted, and the vegetation types were replaced with those of a land-surface model (MATSIRO; Takata et al., 2003) in MIROC5. The level-4 Terra Moderate-Resolution Imaging Spectroradiometer (MODIS) global leaf area index (LAI), obtained from March 2000 to February 2009, was applied to the monthly changes in LAI of both potential vegetation and cropland in each grid (United States Geological Survey [USGS], 2010; https://lpdaac.usgs. 
gov/products/modis_products_table/mod15a2). The distributions of interannual changes in fraction of cropland, and seasonal changes in LAI of both potential vegetation and cropland were arranged for the T85 Gaussian grids $(256 \times 128)$ (approximately 1.4-degree resolution) of climatic data. Interannual and seasonal changes in LAI in each grid were then described with a combination among fractions of both potential vegetation and cropland, and both LAIs. We describe MEGAN in Sect. 2.1, the values of essential parameters for isoprene and monoterpene emissions and the algorithm of the calculation in Sect. 2.2, and the estimation of the influence of global surface air temperature (SAT), downward solar radiation (DSR), the combination thereof, and the expansion of cropland (or land use change) on both emission types in Sect. 2.3.

\subsection{A model for emissions of isoprene and monoterpenes}

The emission of VOCs (in this case, isoprene and monoterpenes) is described in MEGAN as follows:

$\mathrm{VOC}=\varepsilon \cdot \lambda_{\mathrm{LAI}} \cdot \lambda_{\text {age }} \cdot \lambda_{\mathrm{L}} \cdot \lambda_{\mathrm{T}}$,

where $\varepsilon$ is the emission factor of isoprene or monoterpenes that represents the emission of a compound into the canopy under standard conditions, and $\lambda_{\mathrm{LAI}}, \lambda_{\mathrm{age}}, \lambda_{\mathrm{L}}$, and $\lambda_{\mathrm{T}}$ are emission activity factors for LAI, age, light (or photosynthetic photon flux density, PPFD), and temperature, respectively. The standard conditions for the MEGAN canopy-scale emission factors include an LAI of 5 and a canopy with $80 \%$ mature, $10 \%$ growing, and $10 \%$ old foliage; current environmental conditions including a solar angle (degrees from horizon to sun) of 60 degrees, a PPFD transmission (ratio of PPFD at the top of the vegetation canopy to PPFD at the top of the atmosphere) of 0.6 , air temperature of $303 \mathrm{~K}$, humidity of $4 \mathrm{~g} \mathrm{~kg}^{-1}$, wind speed of $3 \mathrm{~m} \mathrm{~s}^{-1}$, and soil moisture of $0.3 \mathrm{~m}^{3} \mathrm{~m}^{-3}$; average canopy environmental conditions of the prior 24 to $240 \mathrm{~h}$ included leaf temperature of $297 \mathrm{~K}$ and PPFD of $200 \mu \mathrm{mol} \mathrm{m} \mathrm{m}^{-2} \mathrm{~s}^{-1}$ for leaves in the sun and $50 \mu \mathrm{mol} \mathrm{m}^{-2} \mathrm{~s}^{-1}$ for leaves in the shade. The original, right-hand side of Eq. (1) is multiplied by a factor for production or loss of VOCs within the canopy $(\rho)$ and emission activity factors for soil moisture $\left(\lambda_{\mathrm{SM}}\right)$ in addition to $\varepsilon, \lambda_{\mathrm{LAI}}, \lambda_{\text {age }}, \lambda_{\mathrm{L}}$, and $\lambda_{\mathrm{T}}$. Here, the values for $\rho$ and $\lambda_{\mathrm{SM}}$ were both assumed to be 1 . Although the influence of ambient $\mathrm{CO}_{2}$ concentration on VOC emissions has been reported (Laothawornkitkul et al., 2009), it was disregarded.

An emission activity factor for LAI is estimated as follows:

$\lambda_{\mathrm{LAI}}=0.49 \cdot \mathrm{LAI} /\left(1+0.2 \cdot \mathrm{LAI}^{2}\right)^{0.5}$.

An emission activity factor for age is estimated as follows:

$\lambda_{\text {age }}=F_{\text {new }} A_{\text {new }}+F_{\text {gro }} A_{\text {gro }}+F_{\text {mat }} A_{\text {mat }}+F_{\text {old }} A_{\text {old }}$, where $F$ is a fraction of foliage, $A$ is relative emission activity, and the subscripts new, gro, mat, and old are new, growing, mature, and old foliages, respectively. The $A_{\text {new }}, A_{\text {gro }}$, $A_{\text {mat }}$, and $A_{\text {old }}$ values were set at $0.05,0.6,1.125$, and 1 for isoprene emission, and 2, 1.8, 0.95, and 1 for monoterpene emission, respectively. The $F_{\text {new }}, F_{\text {gro }}, F_{\text {mat }}$, and $F_{\text {old }}$ are estimated based on the current $\mathrm{LAI}\left(\mathrm{LAI}_{\mathrm{c}}\right)$, LAI of the previous month $\left(\mathrm{LAI}_{\mathrm{p}}\right)$, and monthly temperature $\left(T_{\mathrm{m}}\right)$, in the following three cases: when $\mathrm{LAI}_{\mathrm{c}}=\mathrm{LAI}_{\mathrm{p}}, F_{\text {new }}=0, F_{\text {gro }}=0.1$, $F_{\text {mat }}=0.8$, and $F_{\text {old }}=0.1$; when $\mathrm{LAI}_{\mathrm{c}}<\mathrm{LAI}_{\mathrm{p}}, F_{\text {new }}=0$, $F_{\text {gro }}=0, F_{\text {mat }}=1-F_{\text {old }}$, and $F_{\text {old }}=\left(\mathrm{LAI}_{\mathrm{p}}-\mathrm{LAI}_{\mathrm{c}}\right) / \mathrm{LAI}_{\mathrm{p}}$; and when $\mathrm{LAI}_{\mathrm{c}}>\mathrm{LAI}_{\mathrm{p}}, F_{\text {gro }}=1-F_{\text {new }}-F_{\text {mat }}, F_{\text {old }}=0$, and $F_{\text {new }}$ and $F_{\text {mat }}$ are estimated as follows:

$F_{\text {new }}=1-\mathrm{LAI}_{\mathrm{p}} / \mathrm{LAI}_{\mathrm{c}}$ at $t=\leq t_{i}$,

or $F_{\text {new }}=\left(t_{i} / t\right) \cdot\left(1-\mathrm{LAI}_{\mathrm{p}} / \mathrm{LAI}_{\mathrm{c}}\right)$ at $t>t_{i}$,

and

$$
\begin{gathered}
F_{\mathrm{mat}}=\mathrm{LAI}_{\mathrm{p}} / \mathrm{LAI}_{\mathrm{c}} \text { at } t=\leq t_{m}, \\
\text { or } F_{\mathrm{mat}}=\mathrm{LAI}_{\mathrm{p}} / \mathrm{LAI}_{\mathrm{c}}+\left\{\left(t-t_{m}\right) / t\right\} \\
\cdot\left(1-\mathrm{LAI}_{\mathrm{p}} / \mathrm{LAI}_{\mathrm{c}}\right) \text { at } t>t_{m},
\end{gathered}
$$

where $t$ is time step (in this case, 30 days), $t_{i}$ is the number of days between bud break and the induction of isoprene emission, and $t_{m}$ (or $2.3 \cdot t_{i}$ ) is the number of days between bud break and the initiation of peak isoprene emission. The value for $t_{i}$ is estimated as follows:

$t_{i}=5+0.7 \cdot\left(300-T_{t}\right)$ at $T_{i} \leq 303$,

or $t_{i}=2.9$ at $T_{i}>303$,

where $T_{i}$ is the average ambient air temperature $(\mathrm{K})$ of the preceding time step interval, and $T_{m}$ was used in place of $T_{i}$ in the study.

An emission activity factor of light is estimated after Sakulyanontvittaya et al. (2008), as follows:

$\lambda_{\mathrm{L}}=\sin (a) \cdot\left\lfloor 2.46 \cdot\left\{1+0.0005 \cdot\left(P_{\mathrm{m}}-400\right)\right\} \phi-0.9 \phi^{2}\right\rfloor$

LDF at $\sin (a)>0$,

or $\lambda_{\mathrm{L}}=0$ at $\sin (a)<0$,

where $a$ is solar angle in degrees (in this case, the monthly average value of solar angle only in the daytime), $P_{\mathrm{m}}$ is the monthly average (original daily average) above canopy PPFD $\left(\mu \mathrm{mol} \mathrm{m}^{-2} \mathrm{~s}^{-1}\right)$, LDF is a light-dependence fraction that varies depending on the compound under consideration, and $\phi$ is the above canopy PPFD transmission, which is estimated as follows:

$\phi=P_{\mathrm{ac}} /[\sin (a)\{3000+99 \cdot \cos (2 \pi(\mathrm{DOY}-10) / 365)\}]$,

where $P_{\mathrm{ac}}$ is the above canopy PPFD (here, $P_{\mathrm{m}}$ ), and DOY is the day of year.

An emission activity factor of temperature is estimated as follows:

$\lambda_{\mathrm{T}}=E_{\mathrm{opt}} \cdot C_{\mathrm{T} 2} \cdot \exp \left(C_{\mathrm{T} 1} \cdot x\right) /\left[C_{\mathrm{T} 2}-C_{\mathrm{T} 1} \cdot\left\{1-\exp \left(C_{\mathrm{T} 2} \cdot x\right)\right\}\right]$

for isoprene, and 
$\lambda_{\mathrm{T}}=\exp \left\{\beta \cdot\left(T_{\mathrm{m}}-303\right)\right\}$ for monoterpenes,

where $E_{\mathrm{opt}}=1.75 \cdot \exp \left\{0.08 \cdot\left(T_{\mathrm{d}}-297\right)\right\}, \quad x=\left[1 / T_{\mathrm{opt}}-\right.$ $\left.1 / T_{\mathrm{h}}\right], \quad T_{\mathrm{opt}}=313+\left\{0.6 \cdot\left(T_{240}-297\right)\right\}, \quad C_{\mathrm{T} 1}(=80) \quad$ and $C_{\mathrm{T} 2}(=200)$ are empirical coefficients, $T_{\mathrm{d}}$ is the daily average temperature $(\mathrm{K}), T_{\mathrm{h}}$ is the hourly average temperature $(\mathrm{K}), T_{240}$ is the average air temperature over the past $240 \mathrm{~h}$ $(\mathrm{K})$, and $\beta$ is a temperature dependence $\left(\mathrm{K}^{-1}\right)$, the value of which was set at 0.1. Equation (9) considers that leaves exposed to a past higher temperature release more isoprene than those exposed to a lower past temperature. The influence was disregarded, however, because monthly average ambient temperature at $2 \mathrm{~m}$ above the land surface $\left(T_{\mathrm{m}}\right)$ was used in place of $T_{\mathrm{d}}, T_{\mathrm{h}}$, and $T_{240}$.

\subsection{The parameters for and calculation of isoprene and monoterpene emissions}

Figure 1 shows the distribution of current potential vegetation. Here, ten vegetation types including continental ice (Ice), broadleaf evergreen forest (BEF), broadleaf deciduous forest and woodland (BDFW), mixed coniferous and broadleaf deciduous forest and woodland (MCBDF), coniferous forest and woodland (CFW), high-latitude deciduous forest and woodland (HLDFW), wooded $\mathrm{C} 4$ grassland (WC4G), shrubs and bare ground (SBG), tundra (Tundra), and $\mathrm{C} 3$ grassland $(\mathrm{C} 3 \mathrm{G})$ were classified. The $\mathrm{C} 4$ vegetation fraction during 1986-1995 and SAT (surface air temperature) during September 1957-August 2002 were determined according to Takata et al. (2003), with reference also to Ramankutty and Foley (1999), as shown below. The C4 vegetation fraction and SAT data set were from the International Satellite Land Surface Climatology Project, Initiative II (ISLSCP II; http://daac.ornl.gov/ISLSCP_II/islscpii.shtml) and ECMWF (European Centre for Medium-Range Weather Forecasts) 40 Year Re-analysis (ERA-40) Data (Uppala et al., 2005), respectively.

(1) Ice was converted from other areas, such as Antarctica and most parts of Greenland, where Ramankutty and Foley (1999) did not conduct classification; (2) BEF from Tropical Evergreen Forest/Woodland; (3) BDFW from Tropical Deciduous Forest/Woodland; (4) MCBDF from Temperate Broadleaf Evergreen Forest/Woodland, Temperate Needleleaf Evergreen Forest/Woodland, Temperate Deciduous Forest/Woodland, and Evergreen/Deciduous Mixed Forest (E/DMF) at the lowest monthly SAT of $\geq-3^{\circ}$; (5) CFW from Boreal Evergreen Forest/Woodland, and E/DMF at the lowest monthly SAT of $<-3^{\circ}$ and with $\geq 4$ months at monthly SAT of $\geq 10^{\circ}$; (6) HLDFW from Boreal Deciduous Forest/Woodland, and E/DMF at the lowest monthly SAT of $<-3^{\circ}$ and with $<4$ months at monthly SAT of $\geq 10^{\circ}$; (7) WC4G from Savanna and Dense Shrub (DS) with a C4 vegetation fraction of $>20 \%$; (8) SBG from Open Shrubland and Desert; (9) Tundra from Tundra and Polar

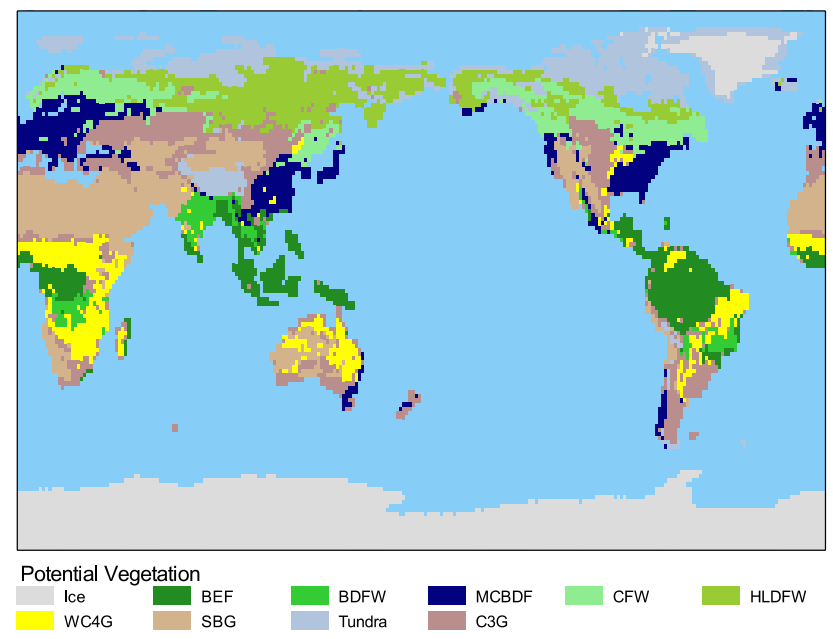

Fig. 1. Global distribution map of potential vegetation: continental ice (Ice), broadleaf evergreen forest (BEF), broadleaf deciduous forest and woodland (BDFW), mixed coniferous and broadleaf deciduous forest and woodland (MCBDF), coniferous forest and woodland (CFW), high latitude deciduous forest and woodland (HLDFW), wooded C4 grassland (WC4G), shrubs and bare ground (SBG), tundra (Tundra), and $\mathrm{C} 3$ grassland $(\mathrm{C} 3 \mathrm{G})$. The vegetation types and distribution are based on Takata et al. (2003) and Ramankutty and Foley (1999), respectively.

Desert/Rock/Ice; (10) C3G from Grassland/Steppe, and Savanna and DS with a $\mathrm{C} 4$ vegetation fraction of $\leq 20 \%$.

The values of $\varepsilon$ and LDF for isoprene or monoterpenes are shown in Table 1. They were set based on Guenther et al. (2006) and Sakulyanontvittaya et al. (2008), respectively. The values were the highest for isoprene in BEF and BDFW, which correspond to tree species extending to low latitudes. The values were the highest for most monoterpenes in CFW and HLDFW, which correspond to tree species extending to high latitudes, or in SBG for limonene and ocimene, respectively. The value for cropland was the lowest for isoprene and most monoterpenes. The values of LDF indicate the higher dependency on land type for isoprene emission and the smaller dependency on land type for monoterpenes, excluding ocimene.

VOC levels (e.g., isoprene, myrcene, sabinene, limonene) were calculated for both vegetation type and cultivation in a grid, using $\mathrm{LAI}_{\mathrm{c}}$ (current month), $\mathrm{LAI}_{\mathrm{p}}$ (previous month), monthly DSR $\left(S_{\mathrm{m}} ; \mathrm{W} \mathrm{m}^{-2}\right), a$, and $T_{\mathrm{m}}$. Monthly above canopy PPFD $\left(P_{\mathrm{m}} ; \mu \mathrm{mol} \mathrm{m} \mathrm{m}^{-2} \mathrm{~s}^{-1}\right)$ was calculated as $k S_{\mathrm{m}}$, where $k\left(\mu \mathrm{mol} \mathrm{J}^{-1}\right)$ is an empirical coefficient and the value was set at 2.3. The monthly average value of $a$ was estimated among positive values of hourly values for $a$ during daytime, after the values were calculated hourly with both the latitude and longitude of a grid and time. The values were summed according to the fraction of cropland $\alpha$ and potential vegetation $(1-\alpha)$. The estimations for eight components (i.e., myrcene, sabinene, limonene, 3 -carene, ocimene, $\beta$-pinene, 
Table 1. The values of emission factors $(\varepsilon)$ and light-dependence fraction (LDF) for isoprene or monoterpenes. The italic values correspond to the maximum values of $\varepsilon$, while the bold values correspond to the minimum vales of $\varepsilon$ excluding continental ice.

\begin{tabular}{|c|c|c|c|c|c|c|c|c|c|c|}
\hline \multirow[t]{3}{*}{ Surface type } & \multicolumn{10}{|l|}{$\varepsilon$} \\
\hline & \multirow[t]{2}{*}{$\begin{array}{l}\text { Isoprene } \\
\mathrm{mgC} \mathrm{m}^{-2} \mathrm{~h}^{-1}\end{array}$} & \multicolumn{9}{|l|}{$\begin{array}{l}\text { Monoterpenes } \\
\times 10^{-3} \mathrm{mgC} \mathrm{m}^{-2} \mathrm{~h}^{-1}\end{array}$} \\
\hline & & Myrcene & sabinene & limonene & 3-carene & ocimene & $\beta$-pinene & $\alpha$-pinene & $\begin{array}{l}\text { other } \\
\text { monoter- } \\
\text { penes }\end{array}$ & Total \\
\hline Continental ice (Ice) & 0 & 0 & 0 & 0 & 0 & 0 & 0 & 0 & 0 & 0 \\
\hline $\begin{array}{l}\text { Broadleaf evergreen forest } \\
\text { (BEF) }\end{array}$ & 11.12 & 19.5 & 12.62 & 35.91 & 4.41 & 118.59 & 35.82 & 31.85 & 137.56 & 396.26 \\
\hline $\begin{array}{l}\text { Broadleaf deciduous forest } \\
\text { and woodland (BDFW) }\end{array}$ & 11.12 & 19.5 & 12.62 & 35.91 & 4.41 & 118.59 & 35.82 & 31.85 & 137.56 & 396.26 \\
\hline $\begin{array}{l}\text { Mixed coniferous and } \\
\text { broadleaf deciduous forest } \\
\text { and woodland (MCBDF) }\end{array}$ & 6.44 & 47.56 & 24.79 & 61.59 & 21.35 & 60.97 & 58.32 & 115.59 & 192.79 & 582.97 \\
\hline $\begin{array}{l}\text { Coniferous forest and } \\
\text { woodland }(\mathrm{CFW})\end{array}$ & 1.76 & 75.71 & 36.97 & 87.26 & 38.38 & 3.44 & 80.91 & 199.32 & 248.12 & 770.12 \\
\hline $\begin{array}{l}\text { High latitude } \\
\text { deciduous forest and } \\
\text { woodland (HLDFW) }\end{array}$ & 0.62 & 75.71 & 36.97 & 87.26 & 38.38 & 3.44 & 80.91 & 199.32 & 248.12 & 770.12 \\
\hline $\begin{array}{l}\text { Wooded C4 grassland } \\
\text { (WC4G) }\end{array}$ & 0.44 & 4.94 & 7.06 & 36.62 & 15.18 & 12.62 & 19.32 & 50.47 & 139.5 & 285.71 \\
\hline $\begin{array}{l}\text { Shrubs and bare ground } \\
\text { (SBG) }\end{array}$ & 9.44 & 18.44 & 15.26 & 153.44 & 5.38 & 90.88 & 39.71 & 45.18 & 280.85 & 649.15 \\
\hline Tundra & 0.44 & 4.94 & 7.06 & 36.62 & 15.18 & 12.62 & 19.32 & 50.47 & 139.5 & 285.71 \\
\hline $\mathrm{C} 3$ grassland $(\mathrm{C} 3 \mathrm{G})$ & 0.44 & 4.94 & 7.06 & 36.62 & 15.18 & 12.62 & 19.32 & 50.47 & 139.5 & 285.71 \\
\hline Cropland & 0.08 & 4.94 & 7.06 & 36.62 & 15.18 & 12.62 & 19.32 & 50.47 & 139.5 & 285.71 \\
\hline LDF value & 0.9999 & 0.05 & 0.1 & 0.05 & 0.05 & 0.8 & 0.1 & 0.1 & 0.1 & - \\
\hline
\end{tabular}

$\alpha$-pinene, and other monoterpenes) were summed to get a value for total monoterpene emissions. Total isoprene and monoterpene emissions on a global scale were calculated while considering the land surface area of grids and excluding both sea and lake surfaces. Variables such as VOC emissions, $\lambda_{\mathrm{L}}$ and $\lambda_{\mathrm{T}}$, are shown as 10 -yr running means; for example, the values in 1854 and 2000 were averaged among those from 1850 to 1859 and from 1996 to 2005, respectively.

We estimated both isoprene and monoterpene emissions in the 11 regions shown in Fig. 2. The A1-A8 regions included parts of Europe, Africa, East Asia, India, Southeast Asia, Oceania, North America, and South America, respectively. These regions had the largest expansion of cultivation since 1850 , as shown in the results. On the other hand, minimal expansion was estimated for regions A9, A10, and A11, which are regions that include latitudes from $90^{\circ} \mathrm{N}$ to $\sim 21^{\circ} \mathrm{N}$, from $\sim 21^{\circ} \mathrm{N}$ to $\sim 21^{\circ} \mathrm{S}$, and from $\sim 21^{\circ} \mathrm{S}$ to $90^{\circ} \mathrm{S}$, excluding the areas in the $\mathrm{A} 1-\mathrm{A} 8$ regions, respectively (Fig. 2). Figure 2 shows the area of each region; region A2 is the largest and A5 is the smallest in A1-A8.

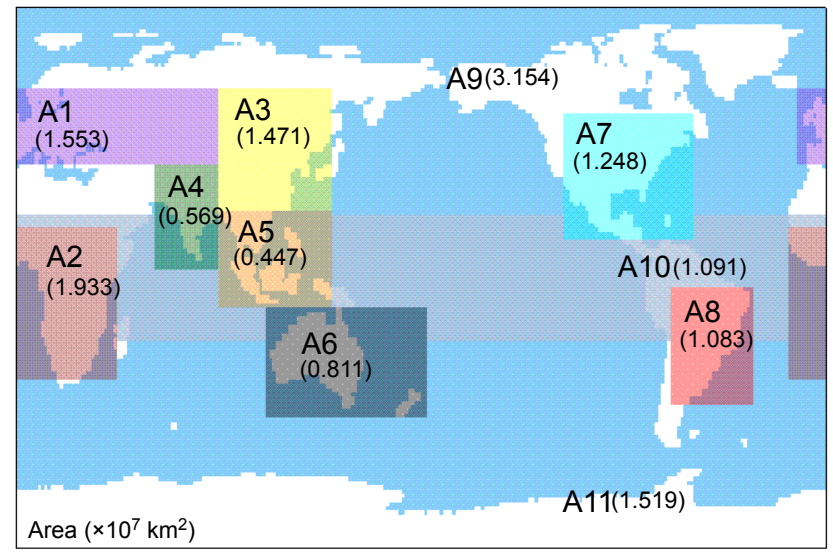

Fig. 2. Targeted areas and related surface (in $10^{7} \mathrm{~km}^{2}$ ). A1-A8 are areas with relatively intensive expansion of cropland (Fig. 4), while A9-A11 are regions with minimal expansion of cropland. Annual global isoprene and monoterpene emissions in each area are shown in Figs. 8 and 9. 

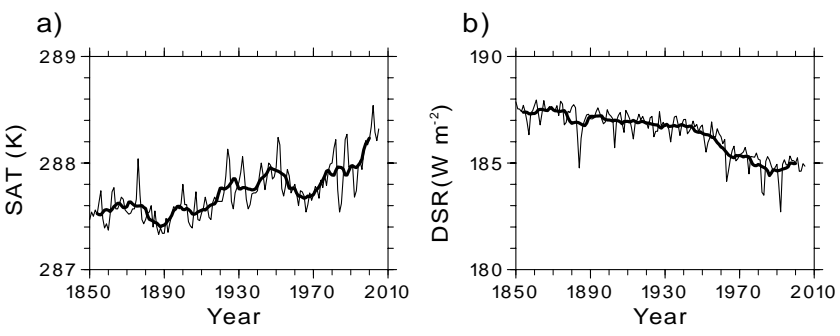

Fig. 3. Global mean surface air temperature (SAT) (a) and downward solar radiation (DSR) above the land surface (b). Thin lines and thick solid lines are temporal and ten-year running means. These were reconstructed by a historical run for the period 1850-2005 with MIROC5 (Watanabe et al., 2010), which is an atmospheric-ocean circulation model, and was used as input data for estimation of global isoprene and monoterpene emissions.

\subsection{Estimation of the influence of both cultivation and climate on emissions}

Both isoprene and monoterpene emissions were calculated with the expansion of cropland in 1850 and climate from 1850 to 2005, and described as 10-yr running means $\left(\operatorname{VOC}_{\mathrm{veg} 1850}(y)\right)$. The value of $\operatorname{VOC}_{\mathrm{veg} 1850}(y)$ was compared to the value for $\operatorname{VOC}(y)$ calculated with the changes in both expansion of cropland and climate, to estimate the influence of expansion of cropland on both types of emissions. Here, $y$ is the year from 1854 to 2000 (see Sect. 2.2). The influence of the expansion of cultivated land on the emissions was estimated as $\operatorname{VOC}(y) / \operatorname{VOC}_{\mathrm{veg} 1850}(y)-1$. The influence of climate was estimated as $\mathrm{VOC}_{\mathrm{veg} 1850}(y) / \mathrm{VOC}_{\mathrm{veg} 1850}$ (1854) 1. The influence of changes in temperature (SAT) and light conditions (DSR) were estimated as $\lambda_{\mathrm{T}}(y) / \lambda_{\mathrm{T}}(1854)-1$ and $\lambda_{\mathrm{L}}(y) / \lambda_{\mathrm{L}}(1854)-1$ for isoprene and monoterpene emissions, respectively. Here, the $\lambda_{\mathrm{L}}(y)$ values for monoterpenes are given as the weighted-average, weighted by emission factors $(\varepsilon)$ of both potential vegetation type and cropland and the areas at all grids for eight species (Table 1), whose values were different as the emissions for most monoterpene species react very little to changes in light conditions while the ocimene emissions react strongly, as mentioned above.

\section{Results}

\subsection{Climate change and cultivation from 1850 to 2005}

Figure 3 shows the interannual variation in both global mean SAT and DSR at $2 \mathrm{~m}$ above the land surface. These values were reproduced by a historical run from 1850 to 2005 with MIROC5 (Watanabe et al., 2010). The SAT gradually increased from the 1850s to the 2000s with some fluctuation; in particular, the periods of global warming observed from the 1890 s to the 1950 s and from the 1970 s to the 2000 s were remarkable. Tatebe et al. (2012) found that the anomalies were similar to those observed in SAT data from 1948 to 2006 and were reanalyzed by the National Centers for Environmental Prediction/National Center for Atmospheric Research (NCEP/NCAR) (Kalnay, 1996). In particular, the magnitude of the reanalyzed interannual SAT was near that of the 10yr running mean of reconstructed interannual SAT. The DSR gradually decreased until the 1950s, fell again sharply from the 1960 s to the 1980 s, and then increased slightly from the mid-1980s.

Figure $4 \mathrm{a}$ and $\mathrm{b}$ show the fraction of cropland in 1850 and in 2000, respectively. In 1850, extensive cultivation was already found in regions A1, A3, A4, and A7 (shown in Fig. 2). Figure $4 \mathrm{c}$ shows the difference in the fraction of cropland between 2000 and 1850. By 1850, cultivation was already extensive in Europe but more extensive in the Ukraine (region A1) and extended eastward into Russia by 2000 (Fig. 4b). Cultivation in 1850 was minimal in western regions of Africa (region A2), but expanded due to a change in distribution of WC4G-type vegetation (yellow area of Fig. 1). Cultivation was initially concentrated around the Yellow River basin in region A3, but over time extended northeastward and southward. Region A4 (Indian subcontinent) was already cultivated in 1850, and by 2000 was much further developed. Very little cultivation was evident in 1850 in region A5; however, by 2000 there appeared to be a strongly concentrated area of cultivation in the Indochina Peninsula, the Malay Peninsula, the island of Sumatra, the Kalimantan/Borneo Islands, and the Philippines. Croplands also expanded around both the east and west coasts of Australia, in particular along the east coast by 2000 in region A6. Cropland was initially concentrated in the eastern portions of the North American continent in 1850 (region A7), but migrated westward into the Midwestern United States, the Prairie Provinces of Canada, and Mexico by 2000. Cultivation also expanded in southern Brazil and in parts of Argentina (region A8) from 1850 . Generally, the expansion of cultivation was related to population increases in countries such as China, India, Indonesia, the United States, and Brazil. In contrast, a change from cropland into other forms of vegetation was found in some areas of both A1 and A7 (Fig. 4c). Cropland expansion of more than $10 \%$ (or 0.1 ) was found only minimally in regions A9-A11.

Figure 5 shows the increase in cultivation and changes in vegetation types in A1 through A11 during the period from 1850-2005 as the ratio of each vegetation area to each targeted land surface area. Cropland increased from $11.5 \%$ to $24.4 \%$, coinciding with a decrease in both $\mathrm{C} 3 \mathrm{G}$ and $\mathrm{MCBDF}$ vegetation during the period 1850-1960 in region A1, subsequently decreased gradually until 1980, and then decreased more rapidly in the 1980s until it reached a value of $20.6 \%$ (Fig. 5a). As shown in Fig. 5b, cropland area in region A2 increased from $2.4 \%$ to $10.1 \%$, mainly due to the replacement of WC4G. Region A3 exhibited a steep increase in cropland after 1980 with cultivation in both MCBDF and SGB lands (Fig. 5c). In region A4, cropland increased from $19.5 \%$ to 
a)

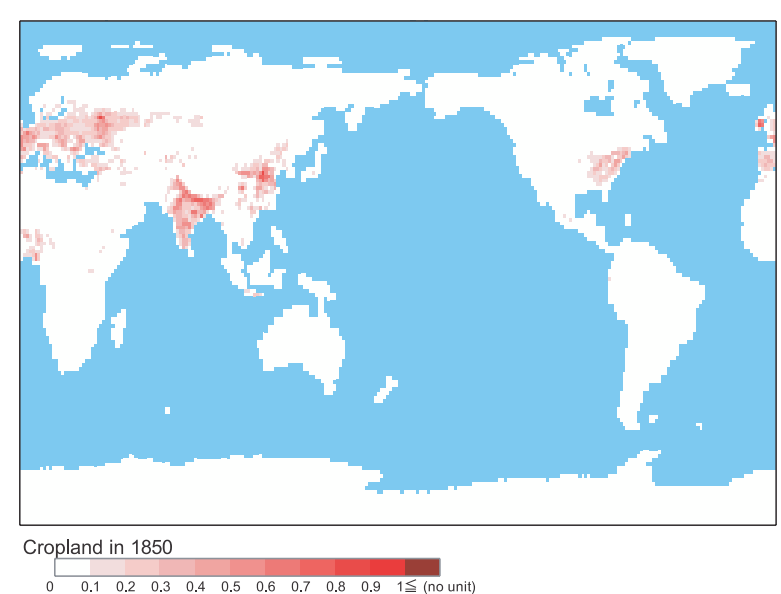

b)

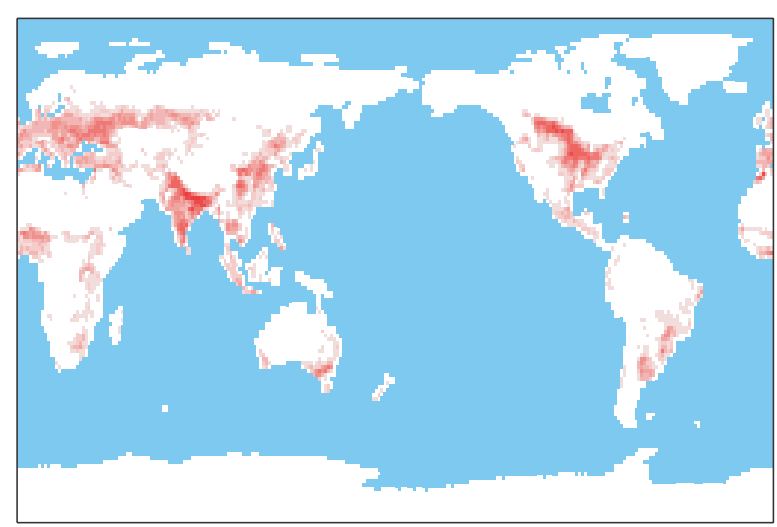

Cropland in 2000

$\begin{array}{lllllllllll}0 & 0.1 & 0.2 & 0.3 & 0.4 & 0.5 & 0.6 & 0.7 & 0.8 & 0.9 & 1 \leqq \text { (no unit) }\end{array}$

c)

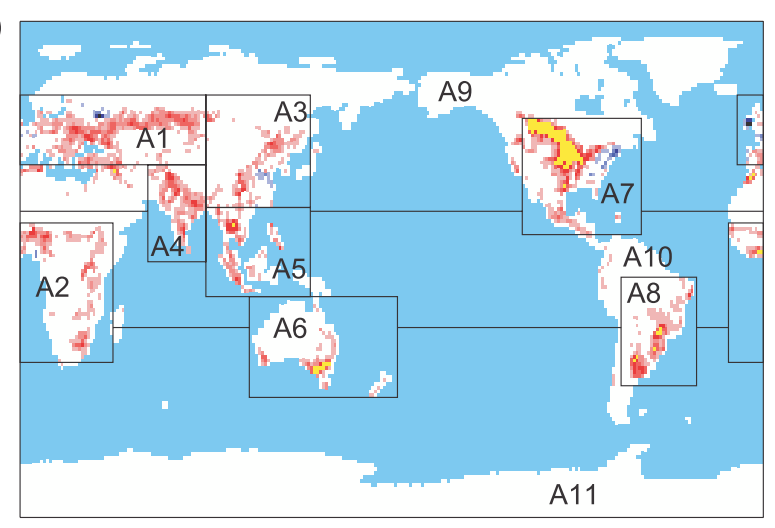

Difference between 2000 - 1850

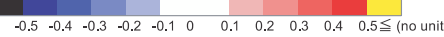

Fig. 4. Global map of fraction of cropland in 1850 (a) and 2000 (b), and the difference between 2000 and 1850 (c). The results are based on Hurtt et al. (2006). Targeted areas (A1-A11) are shown in (c).

$33.1 \%$, with the steeper increase from 1930 to 1960 , but the increase rate slowed after about 1960 (Fig. 5d). Region A5 initially exhibited BEF vegetation of $76.3 \%$ and BDFW vegetation of $10.9 \%$, respectively, but large portions of both were replaced with cropland by 2005 (Fig. 5e). As shown in Fig. 5f, the cropland in region A6 increased clearly from about 1910 with a coinciding decline in SBG and WC4G. In region $\mathrm{A} 7$, cultivation increased constantly along with a decline in both C3G and MCBDF during the period 1850-1940, after which the rate of cropland expansion slowed (Fig. 5g). As shown in Fig. 5h, cropland in region A8 constantly increased along with a decrease in $\mathrm{WC} 4 \mathrm{G}, \mathrm{SBG}$, and BDFW after $\sim 1900$, while the decrease in BEF in this region was relatively lower than these three vegetation types. Regions A9 through A11 exhibited only small changes $(<\sim 1 \%)$ in cultivation (Fig. 5i, k); region A11, which has the third largest area, was $90.1 \%$ ice cover without VOC emissions (Table 1).

Overall, region A5 featured decreases in both BEF and BDFW with the highest emission factors $(\varepsilon)$ of isoprene (Table 1). The decrease in BDFW was also obvious in region A4. However, the decrease in both CFW and HLDFW, with the highest emission factors $(\varepsilon)$ of monoterpenes (Table 1), were relatively small in higher latitudes such as A1, A3, and A7. In these areas, both $\mathrm{C} 3 \mathrm{G}$, which had the lowest $\varepsilon$, and MCBDF, which had a relatively high $\varepsilon$ for monoterpenes, were replaced the most with cropland. Thus, compared to isoprene, the expansion of cropland had a lesser impact on the $\varepsilon$ values of monoterpenes (Table 1).

\subsection{Annual isoprene and monoterpene emissions and the influence of both climate and cultivation during the period 1854-2000}

\subsubsection{Global scale}

Global annual isoprene and monoterpene emissions during the entire study period are shown in Fig. 6a and b. In the figure, red solid lines denote cropland expansion. The values of isoprene and monoterpene were 573 and $69.3 \mathrm{TgC} \mathrm{yr}^{-1}$, respectively, in 1854 , and 540 and $69.5 \mathrm{TgC} \mathrm{yr}^{-1}$, respectively, in the 1990s. The 1990s values are within present estimated and published annual global isoprene and monoterpene emissions: $410-601 \mathrm{TgC}^{-1}$ for isoprene and $33-480 \mathrm{TgC} \mathrm{yr}^{-1}$ for monoterpenes, according to Laothawornkitkul et al. (2009). Arneth et al. (2008) reported that estimates of global terrestrial isoprene emissions are similar while estimates for global monoterpenes emissions vary. Both emissions increased with a steep rise in SAT during the mid-1990s to 2000, and the values were 560 and $71.6 \mathrm{TgC} \mathrm{yr}^{-1}$, respectively, in 2000. The maximum and minimum values for isoprene and monoterpene emissions were 600 (1927) and 530 $\mathrm{TgC} \mathrm{yr}^{-1}$ (1965), and 71.6 (1998) and 67.3 $\mathrm{TgC} \mathrm{yr}^{-1}$ (1890), respectively. Lathière et al. (2005) estimated annual isoprene and monoterpene emissions for the 1850s and 1990s at 409 and $402 \mathrm{TgC} \mathrm{yr}^{-1}$, and 127 and $131 \mathrm{TgC} \mathrm{yr}^{-1}$, respectively. Our estimates are higher for isoprene emissions and lower for monoterpene emissions. However, all of these analyses indicate that annual emissions of isoprene and monoterpenes decreased and increased in the 

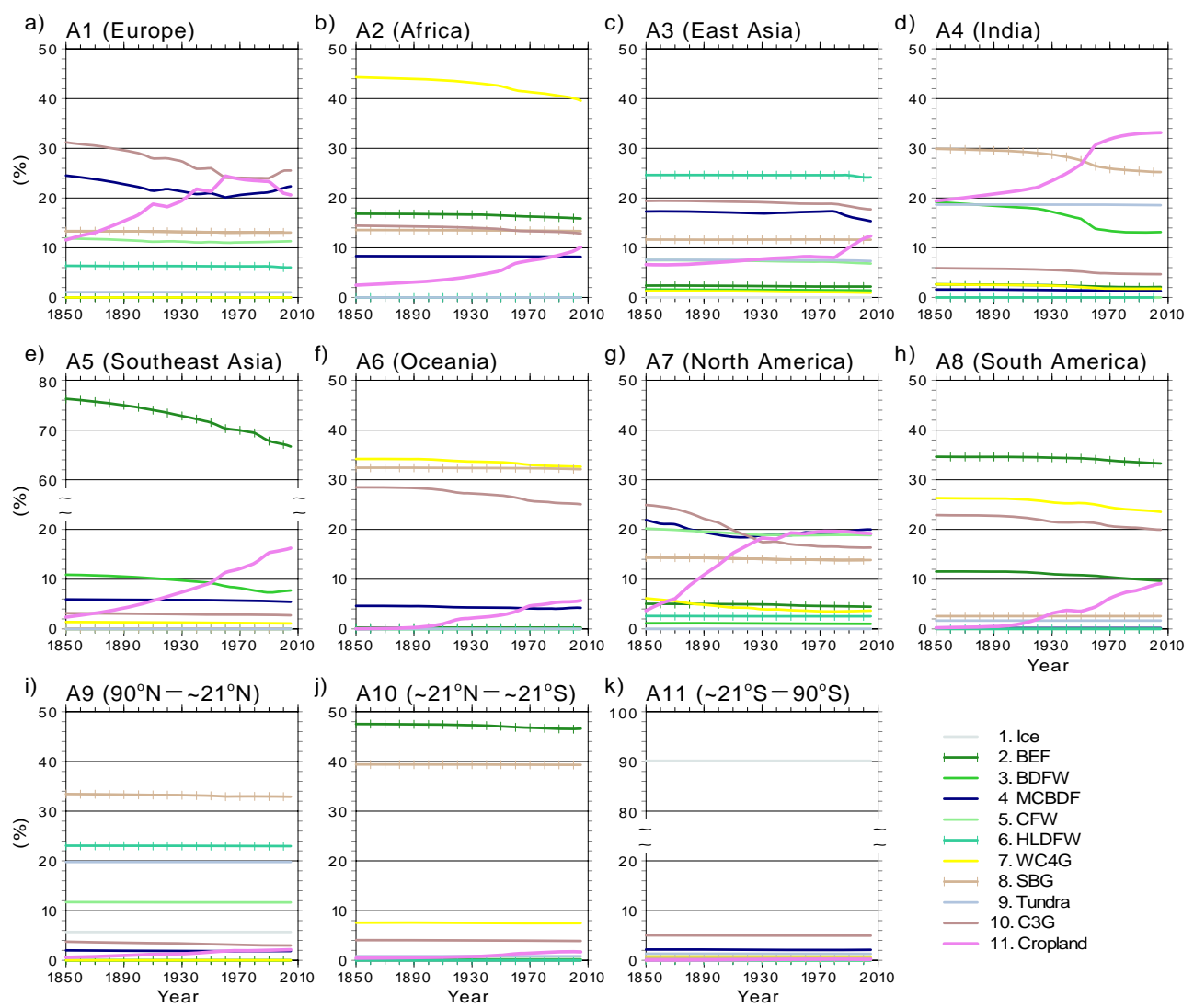

Fig. 5. Interannual changes in the ratio of vegetation area in regions A1 through A11 during the period from 1850-2005.

1990s, respectively, compared to 1850. Lathière et al. (2010) also estimated annual isoprene emissions during the 20th century while considering cropland expansion and estimated

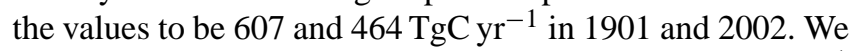
estimated the annual isoprene emission to be $572{\mathrm{TgC} \mathrm{yr}^{-1}}^{-1}$ in 1901. The difference between the 1901 and 2002 values is larger in their estimates than in ours.

Both annual emissions were estimated with cropland expansion from 1850 fluctuating with changes in SAT and DSR (Fig. 3), mainly SAT, during the period from 1854 to 2000 (Fig. 6a and b). The values were estimated to be 604 and 73.2 $\mathrm{TgC} \mathrm{yr}^{-1}$ for isoprene and monoterpenes, respectively, in 2000. Although the changes were similar to the annual emissions estimated by changes in cropland expansion, the differences between the annual emissions with and without changes in cropland expansion gradually become larger, indicating the influence of cropland expansion. The influence of cropland expansion induced a reduction of global emissions by 56.3 and $1.6 \mathrm{TgC} \mathrm{yr}^{-1}$ for isoprene and monoterpenes, respectively, in 2000, and the influences were larger for global isoprene emissions than for global monoterpenes emissions.

Figure $6 \mathrm{c}$ and $\mathrm{d}$ shows the influence of climate, land use (cultivation expansion), SAT, and DSR on global isoprene and monoterpene emissions, respectively. The fluctuations correspond to the annual emissions shown in Fig. 6a and b.
Changes in land use induced a gradual reduction in annual emissions; the minimum values appeared in 2000 , and were $-7.2 \%$ for isoprene and $-2.2 \%$ for monoterpenes. The influences were always larger for isoprene emissions than for monoterpene emissions during the period under study. The influence of SAT on both types of emissions changed with large fluctuations, peaks around the 1920s and the 1950s, and the maximum influence appeared in 1999. The maximum values were $10.0 \%$ for isoprene and $7.7 \%$ for monoterpenes, respectively. The influence of a gradual decrease in DSR on isoprene emissions was evident as a $2.2 \%$ reduction in emissions by 2000. In contrast, monoterpene emissions were minimally influenced by changes in DSR.

Figure $7 \mathrm{a}$ and $\mathrm{b}$ shows the distribution of estimated annual global emissions for isoprene and monoterpenes, respectively, in 2000. Estimated isoprene emissions were concentrated in low latitudes with BEF and BDFW, in particular in BEF (or tropical rain forests), and also in MCBDF (Fig. 1). On the other hand, estimated monoterpene emissions occurred in high latitudes with CFW, HLDFW and $\mathrm{WC} 4 \mathrm{G}$, as well as in low latitudes. Figure $7 \mathrm{c}$ and $\mathrm{d}$ shows the difference in estimated annual global emissions for isoprene and monoterpenes between 2000 and 1854. Isoprene emissions were lower in 2000 than in 1854 in northeast India, Southeast Asia, and in parts of Central America and South 

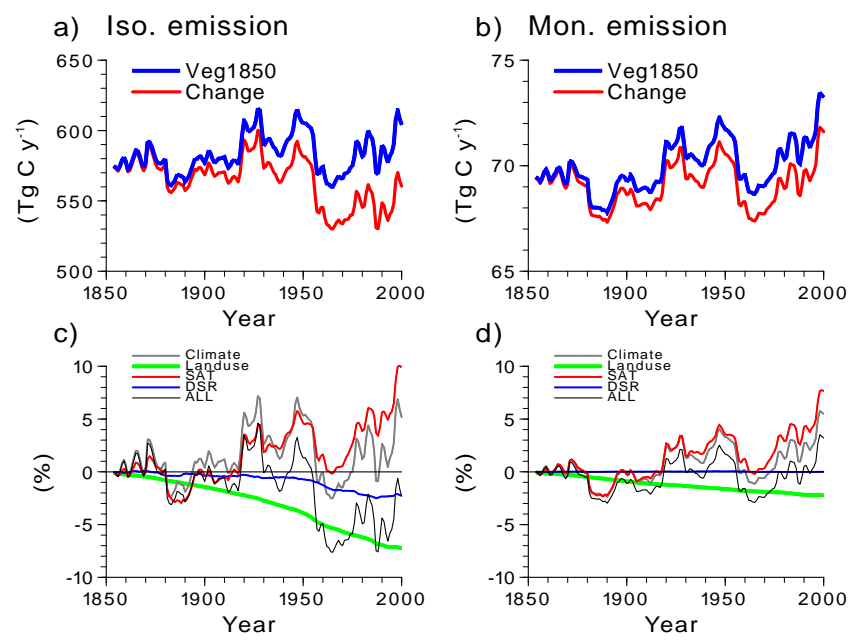

Fig. 6. Interannual changes in estimated annual global isoprene (a) and monoterpene (b) emissions during the period 1854-2000. The red and blue lines in (a) and (b) are the emissions estimated with temporal distribution of vegetation and with constant vegetation distribution in 1850, respectively. The impacts of surface air temperature (SAT; red lines), downward solar radiation (DSR; blue lines), the combination of both SAT and DSR (or climate; gray lines), the extent of cropland (or land use; green thick lines), and the combination thereof (black lines) on annual global isoprene (c) and monoterpene emissions (d). The estimate of the influence is detailed in Sect. 2.3. The results in (a-d) are shown as 10-yr running means, e.g., results in 1854 correspond to average values from 1850 to 1859 .

America, while they were larger in the Amazon. Monoterpene emissions were lower in 2000 than in 1854 in eastern China and in parts of Indochina, India, central North America, and Europe, while they were larger in the Amazon and in parts of North America and Africa. The distribution of the difference between the two types of emissions changed from year to year, compared to those in 1854 (not shown).

\subsubsection{Contribution of isoprene and monoterpene emissions from each area to the global emissions}

Figure 8 shows how regions A1 through A11 contributed to global emissions during the study period. Isoprene emissions were largest in the following order: low latitudes of region A10 with minimal expansion of cultivation, an area of South America in region A8, an area of Africa in region A2, and an area of Southeast Asia in region A5, all of which are distributed in lower latitudes. Monoterpene emissions were the largest in the following order: region $\mathrm{A} 2$, region $\mathrm{A} 8$, region A10, and an area of North America in region A7. Annual isoprene emissions were much larger in these four areas than in any other areas, because both BEF and BDF with the highest $\varepsilon$ are distributed in the areas with high temperature and solar radiation all year round (Fig. 7a). Although CFW and HLDFW with the higher $\varepsilon$ of monoterpenes are distributed in high latitudes with high temperature during a few months in the summer season, the annual emissions were larger in lower latitudes, as in regions A2, A8, and A10, due to their high year-round temperatures. However, the differences (e.g., between A10 and A7) were relatively small, compared to those between the annual isoprene emissions from different regions.

The fluctuation in isoprene emissions in region A8 over the study period was similar to that in region A10, with relatively less change in land use, and the two areas contributed to the global annual emissions the most, which indicates that the emissions were dependent on climate changes rather than on the expansion of cropland. These areas had lower emissions with lower SAT from around 1950 to the 1960s (Fig. 3) than in 1854. The annual emissions in region A5 were similar to those in region A2 from 1850 to the 1890s, but they decreased obviously starting around 1930, and the difference in annual emissions between regions A5 and A2 were the largest at the end of the time series. The influence of expansion of cropland on the annual emissions was the highest in region A5; region A5 likely contributed significantly to the decreases in the annual emissions since the 1950s (Fig. 6a). The annual emissions also decreased with time in regions A4, A3, and A1, although the expansion of cropland had a lesser influence. Region A1 had slight increases in isoprene emissions by reforestation (Fig. 5) in the 1990s. The time series for annual monoterpene emissions were similar among regions $\mathrm{A} 2$ and $\mathrm{A} 8$, both of which had relatively large expansions of cropland, and region A10, which had minimal expansion of cropland.

Figure 9 shows how each vegetation type contributed to global annual emissions. Cropland minimally emitted isoprene according to the lowest emission factors $(\varepsilon)$ (Table 1). Simulations showed that loss of both BEF and BDFW with the highest $\varepsilon$ effectively decreased the annual isoprene emissions in region A5. A slight decrease due to BEF loss appeared in region $\mathrm{A} 2$. In region $\mathrm{A} 8$, a decrease caused by BDFW loss was more obvious than that caused by BEF loss. Decreases in regions A3 and A4 appeared because of the loss of MCBDF and BDFW, respectively. As previously mentioned, the decrease caused by the loss of MCBDF appeared in the 1980s in region $\mathrm{A} 1$, but then reforestation increased the annual emissions around the 1990s.

On the other hand, annual monoterpene emissions from cropland increased with its expansion, and offset the decreases due to other vegetation types to some degree. Thus, the replacement of natural vegetation with cropland decreased the annual emissions of monoterpenes to a lesser extent than it did for isoprene. In region A1, reforestation also increased the annual monoterpene emissions around the 1990s, as it did for isoprene, but the contributions to both annual global emissions was quite small, as shown by Lathière et al. (2006). In regions A2 and A8, WC4G played an important role increasing the annual monoterpene emissions, but not isoprene emissions. 
a)

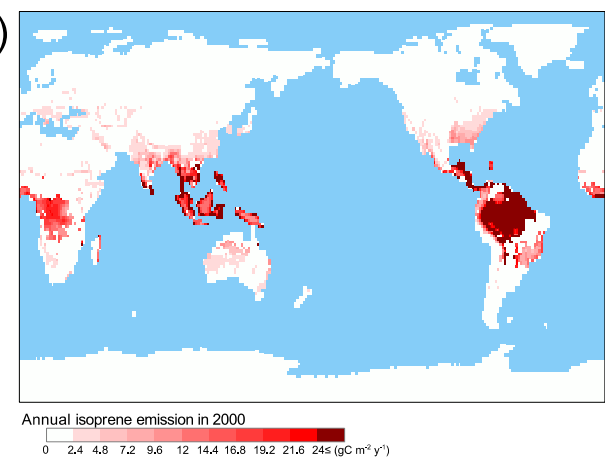

c)

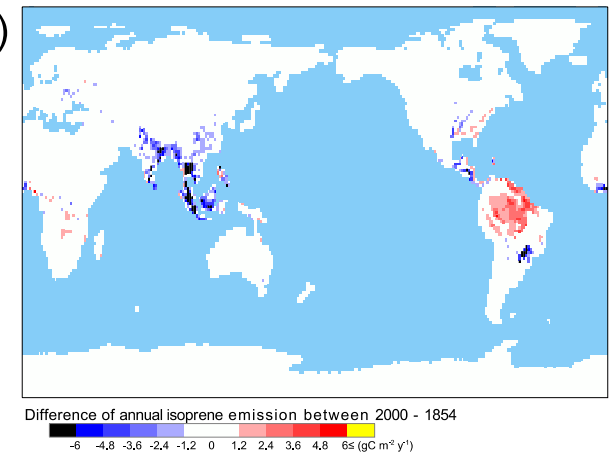

b)

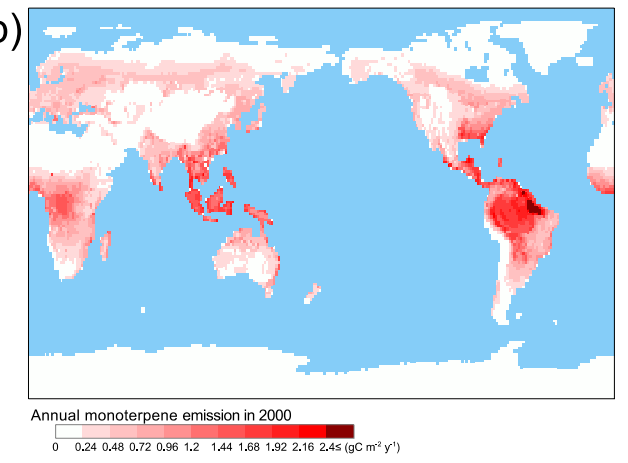

d)

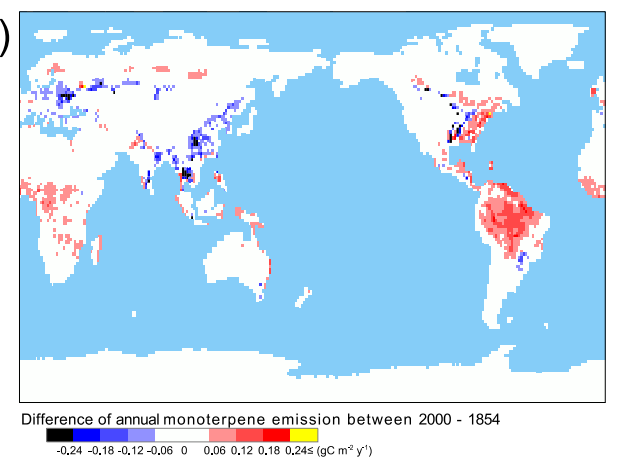

Fig. 7. Distribution of estimated annual global emissions $\left(\mathrm{gC} \mathrm{m}^{-2} \mathrm{yr}^{-1}\right)$ in 2000 , and the differences between 2000 and 1854 for isoprene $(\mathbf{a}$ and $\mathbf{c})$ and monoterpenes (b and $\mathbf{d})$, respectively.
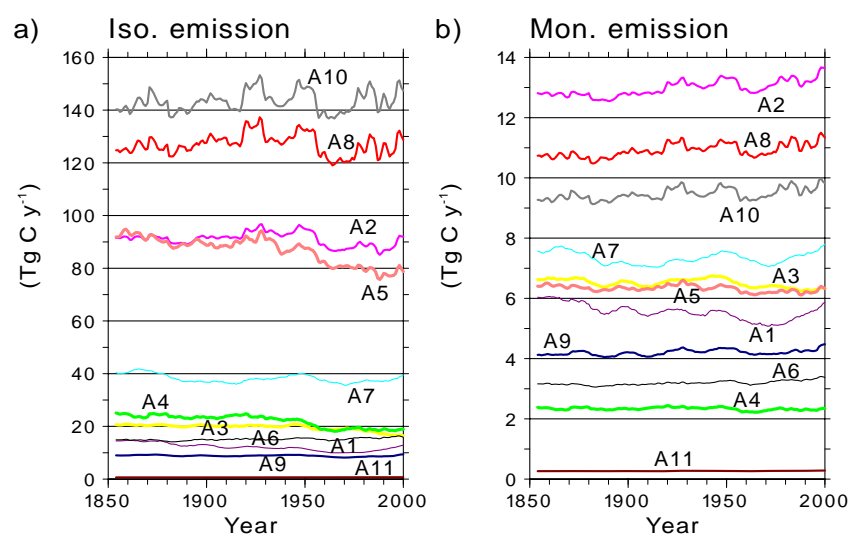

Fig. 8. Interannual changes in estimated annual isoprene (a) and monoterpene (b) emissions during the period 1854-2000 in regions A1 through A11. The results are shown as 10 -yr running means.

\section{Discussion}

We demonstrated the effects of the expansion of cropland and climate change on annual global isoprene and monoterpene emissions during the period 1854-2000. The expansion of cropland had a greater effect on isoprene emissions than on monoterpene emissions (Fig. 6). The expansion of cropland contributed to the annual global emissions of monoterpenes to some degree but contributed only minimally to iso- prene emissions (Fig. 9). The annual global emissions increased for monoterpenes mainly due to global warming, and they decreased for isoprene in the 1990s due to a decline in cropland, compared to those in the preindustrial era. The changes for both compounds between the preindustrial era and the present were consistent with those demonstrated using a static mode simulation by Lathière et al. (2005).

DSR gradually decreased over the entire period, except for a rapid decline from the 1950s to the 1980s and a small increase in the 1990s, while SAT increased overall but with larger fluctuations (Fig. 3). The decline reconstructed by MIROC5 could describe the significant reductions in solar radiation during the past $50 \mathrm{yr}$, reported by a number of studies according to a review by Stanhill and Cohen (2001). The possible causes are an increase in anthropogenic aerosols, other air pollution, and clouds. In addition, the reduction can be attributed to changes in optical properties caused by an increase in atmospheric water vapor due to global warming. The decrease in DSR decreased the annual global isoprene emissions by $2 \%$, while it had little impact on monoterpene emissions. The influence of DSR was the smallest of the three factors considered (Fig. 6). Considering the increase in the ratio of the diffused to direct radiation and the consequent increase in infiltration of solar radiation into regions with deep canopy (e.g., Mercado et al., 2009), the influences may become smaller. 

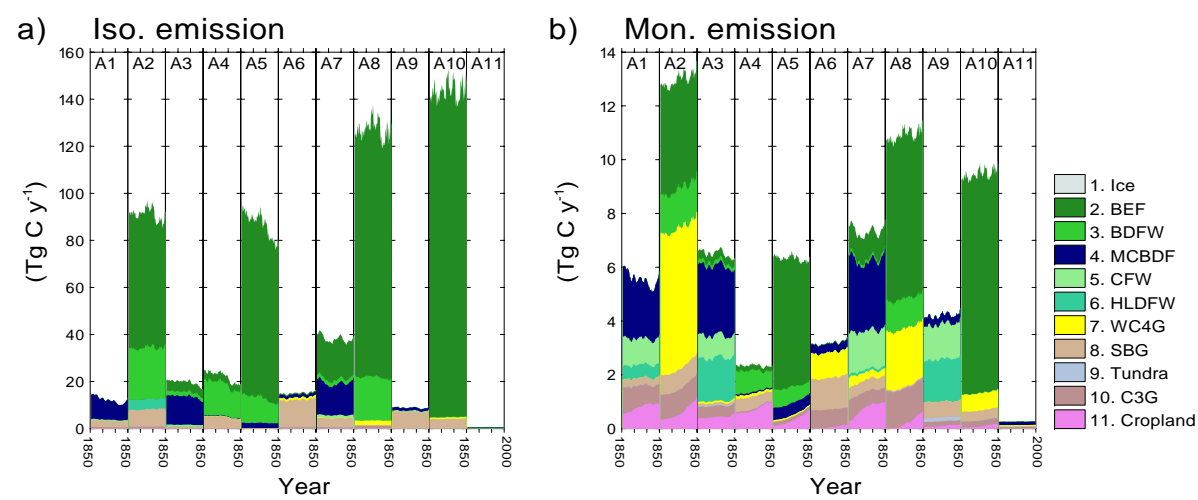

Fig. 9. Interannual changes in contributions of each vegetation type to estimated annual isoprene (a) and monoterpene (b) emissions during the period 1854-2000 in regions A1 through A11. The results are shown as 10-yr running means.

We disregarded the influences of ambient $\mathrm{CO}_{2}$, soil moisture, and other factors on global emissions, and the contributions to both annual global emissions from BEF in Southeast Asia with low latitudes such as in the Amazon were the largest. These findings are further discussed in Sects. 4.1 and 4.2 , respectively. We demonstrated that the influence of cropland on annual global isoprene emissions was the largest in Southeast Asia. The expansion of oil palm plantations with high emissions has occurred on the largest scale in Southeast Asia. However, the influences of this were not considered in the present study. In Sect. 4.3, we discuss how the expansion of this crop in Southeast Asia may influence the estimate of annual global isoprene emissions.

\subsection{Effects of ambient $\mathrm{CO}_{2}$, soil moisture, and other factors neglected in the study}

Our estimate did not consider the influence of ambient $\mathrm{CO}_{2}$ and soil moisture on either isoprene or monoterpene emissions. According to a review by Laothawornkitkul et al. (2009), elevated $\mathrm{CO}_{2}$ levels either increase (Sharkey et al., 1991; Staudt et al., 2001), decrease (Sharkey et al., 1991; Loreto et al., 2001; Rosenstiel et al., 2003; Possell et al., 2004; Vuorinen et al., 2004; Wilkinson et al., 2008), or have no significant effects (Penuelas and Llusia, 1997; Constable et al., 1999; Buckley, 2001; Centritto et al., 2004) on BVOC production and emissions at the whole plant, shoot, and leaf levels. Laothawornkitkul et al. (2009) stated that these contradictory results may be caused by the various factors assessed in each study, including plant species, age, experimental duration, and $\mathrm{CO}_{2}$ concentration, as well as by limitations in experimental design and implementation. On balance, increasing $\mathrm{CO}_{2}$ likely causes a decrease in isoprene emissions from the leaf surface. On the other hand, the decrease might be offset by increases in emissions as a result of increasing vegetation productivity and leaf area growth caused by elevated $\mathrm{CO}_{2}$ levels (Possell et al., 2005; Arneth et al., 2007). Heald et al. (2009) incorporated an empirical model of the observed response of isoprene emissions to both ambient $\mathrm{CO}_{2}$ in the long-term growth environment and short-term changes in intercellular $\mathrm{CO}_{2}$ concentration into the MEGAN embedded within Community Land Model (CLM). They showed that $\mathrm{CO}_{2}$ inhibition has little impact on predictions of present day global isoprene emission. Lathière et al. (2010) estimated annual global isoprene emissions from 1901 to 2002 while considering the suppressive effect of isoprene emissions by rising $\mathrm{CO}_{2}$ and $\mathrm{CO}_{2}$ fertilization of terrestrial vegetation, and reported that the rising atmospheric $\mathrm{CO}_{2}$ caused a $21 \%$ reduction during that period.

Müller et al. (2008) estimated global isoprene emissions from 1995 to 2006 with the MEGAN model, including the effect of isoprene emissions caused by decreased soil moisture. Müller's results indicated that isoprene emissions were about $30 \%$ less than the standard MEGAN estimate (Guenther et al., 2006), mainly because including soil moisture decreased emissions by more than $20 \%$. Moderate drought may decrease, enhance, or have no effect on isoprene and monoterpene emissions, although severe and long-lasting water stress significantly reduces BVOC emissions (Laothawornkitkul et al., 2009). Vegetation classified here as BEF corresponds to tropical or seasonal tropical forests with a dry season and a wet season. The evergreen vegetation is likely to have deep roots (e.g., Canadell et al., 1996; Nepstad et al., 1994), and the consequent large water capacity may maintain leaves all year round (Tanaka et al., 2004). Thus, the emissions from BEF could be minimally reduced by soil moisture even in a dry period. On the other hand, the emissions from SBG and BDFW, with high $\varepsilon$ for both isoprene and monoterpenes around BEF, can be significantly reduced by soil moisture stress during dry periods (Table 1, Fig. 1). Therefore, both of our estimated global emissions may be overestimated because we disregarded the effects of $\mathrm{CO}_{2}$ and soil moisture, even though our findings were within the ranges of the published annual global emissions.

We used monthly instead of hourly data for SAT and DSR for our estimates of emissions. Because the monthly SAT value includes lower air temperatures at nighttime, when 
isoprene emissions do not occur, the use of monthly data might reduce estimated isoprene emissions, but it would have minimal influence on monoterpene estimates. Lathière et al. (2010) used photosynthetically active radiation with a $1 \mathrm{~h}$ interval, based on monthly data and a scheme proposed by dePury and Farquhar (1997), to estimate isoprene emissions. But they did not consider the influence of diurnal patterns on the estimates, and neither did we. Müller et al. (2008) also examined how the differences between air temperature and leaf temperature influence estimated isoprene emissions, and showed that leaves are about 1 or $2 \mathrm{~K}$ warmer than their environment in most forested areas, resulting in emission enhancements of about $10 \%$.

\subsection{Contributions of isoprene and monoterpene emissions in region A5 (Southeast Asia) and in low latitudes to the annual global-scale emissions}

Our estimates demonstrated that region A5 may have made the greatest contribution to annual global isoprene emissions, in particular from BEF (Fig. 9). The data also suggest that this region may have contributed to the annual global monoterpene emissions with constant emissions all year round. These results are consistent with many previous reports (e.g., Guenther et al., 1995, 2006; Müller et al., 2008). However, measurements of BVOC emissions from BEF at the canopy scale in Southeast Asia have only been done by Langford et al. (2010), while a relatively larger number of measurements have been done in Amazon forests (e.g., Helmig et al., 1998; Rinne et al., 2002; Greenberg et al., 2004; Karl et al., 2007; Kuhn et al., 2007; Müller et al., 2008) and in Africa (Greenberg et al., 1999; Serça et al., 2001). Langford et al. (2010) measured BVOC emissions over a tropical rainforest in Malaysian Borneo and found that the emission rates for isoprene and monoterpenes were 4 and 1.8 times lower, respectively, than the default value for tropical forests in the MEGAN model used here, so our estimated emissions for region A5 may be underestimates. On the other hand, the estimated emissions in the abovementioned studies on Amazon forests varied widely. Greenberg et al. (2004) suggested that the different results might be attributable to the species composition of each ecoregion. Thus, the differences among ecoregions in Southeast Asia may be as large as in the Amazon. Langford et al. (2010) argued the need for more direct canopy-scale flux measurements of VOCs from the world's tropical forests.

\subsection{Decrease in annual isoprene emissions in Southeast Asia and the expansion of oil palm}

The simulated isoprene emissions also demonstrated that the influence of land use changes on annual isoprene emissions during the study period were remarkable, in particular in Southeast Asia (Figs. 7-9) and that the effective reduction by the expansion of cropland from BEF, BDFW, and other vegetation was $-15.7 \%$ between 1854 and 2000. In the area $\left(4.47 \times 10^{6} \mathrm{~km}^{2}\right.$; see Fig. 2), an expansion of palm oil cultivation has occurred since the early 1980s; by 2006, the planted area had reached around $6.2 \times 10^{4} \mathrm{~km}^{2}$ (BPS, 2008 ) and $4.2 \times 10^{4} \mathrm{~km}^{2}$ (MOPB, 2008) in Indonesia and Malaysia, respectively. Oil palm is one of highest isoprene emitters (Owen and Penuelas, 2005; Wilkinson et al., 2006; Geron et al., 2006; Misztal et al., 2011), and the total area occupied $2.3 \%$ of the area of region A5. Moreover, the expansion likely continues at the expense of natural forest. The influence of expanded palm oil cultivation on isoprene emission, however, was not considered in the present study. Misztal et al. (2011) measured BVOC emissions, including isoprene from a 15-yr-old palm oil plantation in Malaysian Borneo, with an eddy correlation system, compared the measurements to those from a nearby rainforest measured by Langford et al. (2010) with the same system, and suggested that the isoprene concentrations from the oil palm site were 4 to 8 times greater than the values from the rainforest. Thus, the $9.6 \%$ loss of BEF areas in region A5 during the period from 1854 to 2000 was likely offset or exceeded by subsequent positive effect of substitution with oil palm. Nonetheless, the estimated influences are appropriate before the 1990s, when oil plantations expanded exponentially. The influence will become increasingly important with further expansion after the 2000s. The LAI of an oil palm plantation changes with age, being 2.14 for 5- to 9-yr-old palms and 2.37 for 15-yrold palms in the Malay Peninsula (Awal et al., 2010). Trees aged 9 to $15 \mathrm{yr}$ are the most productive (Sheil et al., 2009), which implies that isoprene may be emitted the most during those years. Trees become too tall to harvest the fruits after 25 to $30 \mathrm{yr}$, and some long-established plantations in Malaysia have already been replaced for the third time (Basiron, 2007), indicating that the isoprene emissions should weaken during the replacement. Palms mature so rapidly that the fruit can be harvested as soon as 2 to $3 \mathrm{yr}$ after planting (Basiron, 2007). Thus, such changes in the characteristics of oil palm with age and plantation management will be essential for estimating isoprene emissions with the expansion of cropland area in Southeast Asia.

\section{Conclusions}

We estimated annual global isoprene and monoterpene emissions since the beginning of the industrial age (1850s) with the MEGAN model (Guenther et al., 2006), based on SAT and DSR reconstructed by a historical run with MIROC5, and temporal expansion of cropland. We investigated the influences of SAT, DSR, and cropland expansion on both annual emissions. The expansion of cropland had a lesser effect on annual global monoterpene emissions $(\sim 2 \%$ reduction) than on isoprene emissions ( $\sim 7 \%$ reduction), because the cropland also contributed substantially to the emission of the former but not the latter. A gradual decrease in 
SDR decreased isoprene emissions by $2 \%$ between 1854 and 2000 , but only slightly decreased monoterpene emissions because most monoterpenes (except ocimene) react minimally to solar radiation. The gradual rise in SAT with large fluctuations increased isoprene and monoterpene emissions by $9 \%$ and $7 \%$, respectively, between 1854 and 2000 . The changes in both emissions depended on the balance between the increase caused by increasing temperature and the reduction caused by the expansion of cultivation, and annual global isoprene and monoterpene emissions decreased and increased in 2000 , respectively. The influence of cultivation changes on annual global isoprene emissions were most remarkable in Southeast Asia, because of the replacement of BEF, which has the most constant and highest emissions, with cropland, which has the lowest emissions. On the other hand, since oil palm plantations with very high emissions have expanded since the 1980s in this area, we discussed the possible influence of oil palm plantations on the estimated influence of land use changes. Specifically, we suggested that the expansion of oil palm cultivation will likely offset or exceed the decline in emissions caused by loss of broad-leaved evergreen forest (or tropical rainforest) in the 2000s.

Acknowledgements. This research was supported by the Environment Research and Technology Development Fund (A-0902) of the Ministry of the Environment, Japan. We are grateful to Takashi Sakamoto of the University of Tokyo, and Hiroaki Tatebe and Yoshiki Komuro of Japan Agency for Marine-Earth Science and Technology for their helpful comments on a historical climate data reproduced by MIROC5. We also thank Sou Matsunaga of Hokkaido University, Akira Tani of University of Shizuoka, Takuya Saito of National Institute for Environment Studies, and Motonori Okumura of Kyoto University for helpful suggestions.

Edited by: A. B. Guenther

\section{References}

Andreae, M. O. and Crutzen, P. J.: Atmospheric aerosols: Biogeochemical sources and role in atmospheric chemistry, Science, 276, 1052-1058, doi:10.1126/science.276.5315.1052, 1997.

Arneth, A., Niinemets, Ü., Pressley, S., Bäck, J., Hari, P., Karl, T., Noe, S., Prentice, I. C., Serça, D., Hickler, T., Wolf, A., and Smith, B.: Process-based estimates of terrestrial ecosystem isoprene emissions: incorporating the effects of a direct $\mathrm{CO}_{2}$-isoprene interaction, Atmos. Chem. Phys., 7, 31-53, doi:10.5194/acp-7-31-2007, 2007.

Arneth, A., Monson, R. K., Schurgers, G., Niinemets, Ü., and Palmer, P. I.: Why are estimates of global terrestrial isoprene emissions so similar (and why is this not so for monoterpenes)?, Atmos. Chem. Phys., 8, 4605-4620, doi:10.5194/acp-8-46052008, 2008.

Awal, M. A., Wan Ishak, W. I., and Bockari-Gevao, S. M.: Determination of leaf area index for oil palm plantation using hemispherical photography technique, J. Sci. Technol., 18, 23-32, 2010.
Badan Pusat Statistik (BPS): Statisitik Kelapa Sawit Indnesia 2007, Badan Pusat Statistik, Jakarta, 2008.

Basiron, Y.: Palm oil production through sustainable plantations, Eur. J. Lip. Sci. Technol., 109, 289-295, doi:10.1002/ejlt.200600223, 2007.

Buckley, P. T.: Isoprene emissions from a Florida scrub oak species grown in ambient and elevated carbon dioxide, Atmos. Environ., 35, 631-634, doi:10.1016/s1352-2310(00)00332-0, 2001.

Canadell, J., Jackson, R. B., Ehleringer, J. R., Mooney, H. A., Sala, O. E., and Schulze, E. D.: Maximum rooting depth of vegetation types at the global scale, Oecologia, 108, 583-595, doi:10.1007/bf00329030, 1996.

Centritto, M., Nascetti, P., Petrilli, L., Raschi, A., and Loreto, F.: Profiles of isoprene emission and photosynthetic parameters in hybrid poplars exposed to free-air $\mathrm{CO}_{2}$ enrichment, Plant Cell Environ., 27, 403-412, doi:10.1111/j.1365-3040.2003.01156.x, 2004.

Chung, S. H. and Seinfeld, J. H.: Global distribution and climate forcing of carbonaceous aerosols, J. Geophys. Res.-Atmos., 107, 4407, doi:10.1029/2001jd001397, 2002.

Claeys, M., Graham, B., Vas, G., Wang, W., Vermeylen, R., Pashynska, V., Cafmeyer, J., Guyon, P., Andreae, M. O., Artaxo, P., and Maenhaut, W.: Formation of secondary organic aerosols through photooxidation of isoprene, Science, 303, 1173-1176, doi:10.1126/science.1092805, 2004.

Constable, J. V. H., Litvak, M. E., Greenberg, J. P., and Monson, R. $\mathrm{K}$. : Monoterpene emission from coniferous trees in response to elevated $\mathrm{CO}_{2}$ concentration and climate warming, Glob. Change Biol., 5, 255-267, 1999.

Davison, B., Brunner, A., Ammann, C., Spirig, C., Jocher, M., and Neftel, A.: Cut-induced VOC emissions from agricultural grasslands, Plant Biol., 10, 76-85, doi:10.1055/s-2007-965043, 2008.

dePury, D. G. G. and Farquhar, G. D.: Simple scaling of photosynthesis from leaves to canopies without the errors of big-leaf models, Plant Cell Environ., 20, 537-557, doi:10.1111/j.13653040.1997.00094.x, 1997.

Engelhart, G. J., Asa-Awuku, A., Nenes, A., and Pandis, S. N.: CCN activity and droplet growth kinetics of fresh and aged monoterpene secondary organic aerosol, Atmos. Chem. Phys., 8, 39373949, doi:10.5194/acp-8-3937-2008, 2008.

Fehsenfeld, F., Calvert, J., Fall, R., Goldan, P., Guenther, A. B., Hewitt, C. N., Lamb, B., Liu, S., Trainer, M., Westberg, H., and Zimmerman, P.: Emissions of volatile organic compounds from vegetation and the implications for atmospheric chemistry, Global Biogeochem. Cy., 6, 389-430, 1992.

Folland, C. K., Rayner, N. A., Brown, S. J., Smith, T. M., Shen, S. S. P., Parker, D. E., Macadam, I., Jones, P. D., Jones, R. N., Nicholls, N., and Sexton, D. M. H.: Global temperature change and its uncertainties since 1861, Geophys. Res. Lett., 28, 26212624, doi:10.1029/2001gl012877, 2001.

Geron, C., Owen, S., Guenther, A., Greenberg, J., Rasmussen, R., Bai, J. H., Li, Q. J., and Baker, B.: Volatile organic compounds from vegetation in southern Yunnan Province, China: Emission rates and some potential regional implications, Atmos. Environ., 40, 1759-1773, doi:10.1016/j.atmosenv.2005.11.022, 2006.

Greenberg, J. P., Guenther, A. B., Madronich, S., Baugh, W., Ginoux, P., Druilhet, A., Delmas, R., and Delon, C.: Biogenic volatile organic compound emissions in central Africa during the Experiment for the Regional Sources and Sinks of 
Oxidants (EXPRESSO) biomass burning season, J. Geophys. Res.-Atmos., 104, 30659-30671, doi:10.1029/1999jd900475, 1999.

Greenberg, J. P., Guenther, A. B., Petron, G., Wiedinmyer, C., Vega, O., Gatti, L. V., Tota, J., and Fisch, G.: Biogenic VOC emissions from forested Amazonian landscapes, Glob. Change Biol., 10, 651-662, doi:10.1111/j.1365-2486.2004.00758.x, 2004.

Guenther, A. B., Zimmerman, P. R., Harley, P. C., Monson, R. K., and Fall, R.: Isoprene and monoterpene emission rate variability - model evaluations and sensitivity analyses, J. Geophys. Res.Atmos., 98, 12609-12617, doi:10.1029/93jd00527, 1993.

Guenther, A., Hewitt, C. N., Erickson, D., Fall, R., Geron, C., Graedel, T., Harley, P., Klinger, L., Lerdau, M., McKay, W. A., Pierce, T., Scholes, B., Steinbrecher, R., Tallamraju, R., Taylor, J., and Zimmerman, P.: A global model of natural volatile organic compound emissions, J. Geophys. Res.-Atmos., 100, 8873-8892, doi:10.1029/94jd02950, 1995.

Guenther, A., Karl, T., Harley, P., Wiedinmyer, C., Palmer, P. I., and Geron, C.: Estimates of global terrestrial isoprene emissions using MEGAN (Model of Emissions of Gases and Aerosols from Nature), Atmos. Chem. Phys., 6, 3181-3210, doi:10.5194/acp-63181-2006, 2006.

Heald, C. L., Wilkinson, M. J., Monson, R. K., Alo, C. A., Wang, G. L., and Guenther, A.: Response of isoprene emission to ambient $\mathrm{CO} 2$ changes and implications for global budgets, Glob. Change Biol., 15, 1127-1140, doi:10.1111/j.1365-2486.2008.01802.x, 2009.

Helmig, D., Balsley, B., Davis, K., Kuck, L. R., Jensen, M., Bognar, J., Smith, T., Arrieta, R. V., Rodriguez, R., and Birks, J. W.: Vertical profiling and determination of landscape fluxes of biogenic nonmethane hydrocarbons within the planetary boundary layer in the Peruvian Amazon, J. Geophys. Res.-Atmos., 103, 2551925532, doi:10.1029/98jd01023, 1998.

Henze, D. K. and Seinfeld, J. H.: Global secondary organic aerosol from isoprene oxidation, Geophys. Res. Lett., 33, L09812, doi:10.1029/2006g1025976, 2006.

Hurtt, G. C., Frolking, S., Fearon, M. G., Moore, B., Shevliakova, E., Malyshev, S., Pacala, S. W., and Houghton, R. A.: The underpinnings of land-use history: three centuries of global gridded land-use transitions, wood-harvest activity, and resulting secondary lands, Glob. Change Biol., 12, 1208-1229, doi:10.1111/j.1365-2486.2006.01150.x, 2006.

Ion, A. C., Vermeylen, R., Kourtchev, I., Cafmeyer, J., Chi, X., Gelencsér, A., Maenhaut, W., and Claeys, M.: Polar organic compounds in rural $\mathrm{PM}_{2.5}$ aerosols from K-puszta, Hungary, during a 2003 summer field campaign: Sources and diel variations, Atmos. Chem. Phys., 5, 1805-1814, doi:10.5194/acp-5-1805-2005, 2005.

Jang, M. S., Czoschke, N. M., Lee, S., and Kamens, R. M.: Heterogeneous atmospheric aerosol production by acidcatalyzed particle-phase reactions, Science, 298, 814-817, doi:10.1126/science.1075798, 2002.

Kalnay, E., Kanamitsu, M., Kistler, R., Collins, W., Deaven, D., Gandin, L., Iredell, M., Saha, S., White, G., Woollen, J., Zhu, Y., Chelliah, M., Ebisuzaki, W., Higgins, W., Janowiak, J., Mo, K. C., Ropelewski, C., Wang, J., Leetmaa, A., Reynolds, R., Jenne, R., and Joseph, D.: The NCEP/NCAR 40-year reanalysis project, B. Am. Meteorol. Soc., 77, 437-471, doi:10.1175/15200477(1996)077;0437:tnyrp ¿2.0.co;2, 1996.
Karl, T., Guenther, A., Yokelson, R. J., Greenberg, J., Potosnak, M., Blake, D. R., and Artaxo, P.: The tropical forest and fire emissions experiment: Emission, chemistry, and transport of biogenic volatile organic compounds in the lower atmosphere over Amazonia, J. Geophys. Res.-Atmos., 112, D18302, doi:10.1029/2007jd008539, 2007.

Keeling, C. I. and Bohlmann, J.: Genes, enzymes and chemicals of terpenoid diversity in the constitutive and induced defence of conifers against insects and pathogens, New Phytol., 170, 657675, doi:10.1111/j.1469-8137.2006.01716.x, 2006.

Kirstine, W., Galbally, I., Ye, Y. R., and Hooper, M.: Emissions of volatile organic compounds (primarily oxygenated species) from pasture, J. Geophys. Res.-Atmos., 103, 10605-10619, doi:10.1029/97jd03753, 1998.

König, G., Brunda, M., Puxbaum, H., Hewitt, C. N., Duckham, S. C., and Rudolph, J.: Relative contribution of oxygenated hydrocarbons to the total biogenic voc emissions of selected midEuropean agricultural and natural plant-species, Atmos. Environ., 29, 861-874, doi:10.1016/1352-2310(95)00026-u, 1995.

Kourtchev, I., Ruuskanen, T., Maenhaut, W., Kulmala, M., and Claeys, M.: Observation of 2-methyltetrols and related photo-oxidation products of isoprene in boreal forest aerosols from Hyytiälä, Finland, Atmos. Chem. Phys., 5, 2761-2770, doi:10.5194/acp-5-2761-2005, 2005.

Kuhn, U., Rottenberger, S., Biesenthal, T., Wolf, A., Schebeske, G., Ciccioli, P., Brancaleoni, E., Frattoni, M., Tavares, T. M., and Kesselmeier, J.: Seasonal differences in isoprene and light-dependent monoterpene emission by Amazonian tree species, Glob. Change Biol., 10, 663-682, doi:10.1111/j.15298817.2003.00771.x, 2004.

Kuhn, U., Andreae, M. O., Ammann, C., Araújo, A. C., Brancaleoni, E., Ciccioli, P., Dindorf, T., Frattoni, M., Gatti, L. V., Ganzeveld, L., Kruijt, B., Lelieveld, J., Lloyd, J., Meixner, F. X., Nobre, A. D., Pöschl, U., Spirig, C., Stefani, P., Thielmann, A., Valentini, R., and Kesselmeier, J.: Isoprene and monoterpene fluxes from Central Amazonian rainforest inferred from towerbased and airborne measurements, and implications on the atmospheric chemistry and the local carbon budget, Atmos. Chem. Phys., 7, 2855-2879, doi:10.5194/acp-7-2855-2007, 2007.

Langford, B., Misztal, P. K., Nemitz, E., Davison, B., Helfter, C., Pugh, T. A. M., MacKenzie, A. R., Lim, S. F., and Hewitt, C. N.: Fluxes and concentrations of volatile organic compounds from a South-East Asian tropical rainforest, Atmos. Chem. Phys., 10, 8391-8412, doi:10.5194/acp-10-8391-2010, 2010.

Laothawornkitkul, J., Taylor, J. E., Paul, N. D., and Hewitt, C. N.: Biogenic volatile organic compounds in the Earth system, New Phytol., 184, 276-276, 2009.

Lathière, J., Hauglustaine, D. A., De Noblet-Ducoudré, N., Krinner, G., and Folberth, G. A.: Past and future changes in biogenic volatile organic compound emissions simulated with a global dynamic vegetation model, Geophys. Res. Lett., 32, L20818, doi:10.1029/2005g1024164, 2005.

Lathière, J., Hauglustaine, D. A., Friend, A. D., De NobletDucoudré, N., Viovy, N., and Folberth, G. A.: Impact of climate variability and land use changes on global biogenic volatile organic compound emissions, Atmos. Chem. Phys., 6, 2129-2146, doi:10.5194/acp-6-2129-2006, 2006.

Lathière, J., Hewitt, C. N., and Beerling, D. J.: Sensitivity of isoprene emissions from the terrestrial biosphere to 
20th century changes in atmospheric $\mathrm{CO}_{2}$ concentration, climate, and land use, Global Biogeochem. Cy., 24, Gb1004, doi:10.1029/2009gb003548, 2010.

Lean, J., Rottman, G., Harder, J., and Kopp, G.: SORCE contributions to new understanding of global change and solar variability, Sol. Phys., 230, 27-53, doi:10.1007/s11207-005-1527-2, 2005.

Loreto, F., Fischbach, R. J., Schnitzler, J. P., Ciccioli, P., Brancaleoni, E., Calfapietra, C., and Seufert, G.: Monoterpene emission and monoterpene synthase activities in the Mediterranean evergreen oak Quercus ilex L. grown at elevated $\mathrm{CO}_{2}$ concentrations, Glob. Change Biol., 7, 709-717, doi:10.1046/j.13541013.2001.00442.x, 2001.

Malaysian Palm Oil Board (MOPB): Malaysian oil palm statistics 2007, 27th Edn., Malaysian Palm Oil Board, Kuala Lumpur, 2008.

Matsunaga, S., Mochida, M., and Kawamura, K.: Growth of organic aerosols by biogenic semi-volatile carbonyls in the forestal atmosphere, Atmos. Environ., 37, 2045-2050, doi:10.1016/s13522310(03)00089-x, 2003.

Mercado, L. M., Bellouin, N., Sitch, S., Boucher, O., Huntingford, C., Wild, M., and Cox, P. M.: Impact of changes in diffuse radiation on the global land carbon sink, Nature, 458, 1014-1018, doi:10.1038/nature07949, 2009.

Misztal, P. K., Nemitz, E., Langford, B., Di Marco, C. F., Phillips, G. J., Hewitt, C. N., MacKenzie, A. R., Owen, S. M., Fowler, D., Heal, M. R., and Cape, J. N.: Direct ecosystem fluxes of volatile organic compounds from oil palms in South-East Asia, Atmos. Chem. Phys., 11, 8995-9017, doi:10.5194/acp-11-89952011, 2011.

Müller, J.-F., Stavrakou, T., Wallens, S., De Smedt, I., Van Roozendael, M., Potosnak, M. J., Rinne, J., Munger, B., Goldstein, A., and Guenther, A. B.: Global isoprene emissions estimated using MEGAN, ECMWF analyses and a detailed canopy environment model, Atmos. Chem. Phys., 8, 1329-1341, doi:10.5194/acp-81329-2008, 2008.

Nepstad, D. C., Decarvalho, C. R., Davidson, E. A., Jipp, P. H., Lefebvre, P. A., Negreiros, G. H., Dasilva, E. D., Stone, T. A., Trumbore, S. E., and Vieira, S.: The role of deep roots in the hydrological and carbon cycles of amazonian forests and pastures, Nature, 372, 666-669, doi:10.1038/372666a0, 1994.

Novakov, T. and Penner, J. E.: Large contribution of organic aerosols to cloud-condensation-nuclei concentrations, Nature, 365, 823-826, doi:10.1038/365823a0, 1993.

Owen, S. M., Boissard, C., and Hewitt, C. N.: Volatile organic compounds (VOCs) emitted from 40 Mediterranean plant species: VOC speciation and extrapolation to habitat scale, Atmos. Environ., 35, 5393-5409, doi:10.1016/s1352-2310(01)00302-8, 2001

Owen, S. M. and Penuelas, J.: Opportunistic emissions of volatile isoprenoids, Trends Plant Sci., 10, 420-426, doi:10.1016/j.tplants.2005.07.010, 2005.

Paulot, F., Crounse, J. D., Kjaergaard, H. G., Kroll, J. H., Seinfeld, J. H., and Wennberg, P. O.: Isoprene photooxidation: new insights into the production of acids and organic nitrates, Atmos. Chem. Phys., 9, 1479-1501, doi:10.5194/acp-9-1479-2009, 2009.

Penuelas, J. and Llusia, J.: Effects of carbon dioxide, water supply, and seasonality on terpene content and emission by Rosmarinus officinalis, J. Chem. Ecol., 23, 979-993, doi:10.1023/B:JOEC.0000006383.29650.d7, 1997.
Possell, M., Heath, J., Nicholas Hewitt, C., Ayres, E., and Kerstiens, G.: Interactive effects of elevated $\mathrm{CO}_{2}$ and soil fertility on isoprene emissions from Quercus robur, Glob. Change Biol., 10, 1835-1843, doi:10.1111/j.1365-2486.2004.00845.x, 2004.

Possell, M., Hewitt, C. N., and Beerling, D. J.: The effects of glacial atmospheric $\mathrm{CO}_{2}$ concentrations and climate on isoprene emissions by vascular plants, Glob. Change Biol., 11, 60-69, doi:10.1111/j.1365-2486.2004.00889.x, 2005.

Ramankutty, N. and Foley, J. A.: Estimating historical changes in global land cover: Croplands from 1700 to 1992, Global Biogeochem. Cy., 13, 997-1027, doi:10.1029/1999gb900046, 1999.

Rinne, H. J. I., Guenther, A. B., Greenberg, J. P., and Harley, P. C.: Isoprene and monoterpene fluxes measured above Amazonian rainforest and their dependence on light and temperature, Atmos. Environ., 36, 2421-2426, doi:10.1016/s1352-2310(01)00523-4, 2002.

Rosenstiel, T. N., Potosnak, M. J., Griffin, K. L., Fall, R., and Monson, R. K.: Increased $\mathrm{CO}_{2}$ uncouples growth from isoprene emission in an agriforest ecosystem, Nature, 421, 256-259, doi:10.1038/nature01312, 2003.

Sakulyanontvittaya, T., Duhl, T., Wiedinmyer, C., Helmig, D., Matsunaga, S., Potosnak, M., Milford, J., and Guenther, A.: Monoterpene and sesquiterpene emission estimates for the United States, Environ. Sci. Technol., 42, 1623-1629, doi:10.1021/es702274e, 2008.

Serça, D., Guenther, A., Klinger, L., Vierling, L., Harley, P., Druilhet, A., Greenberg, J., Baker, B., Baugh, W., Bouka-Biona, C., and Loemba-Ndembi, J.: EXPRESSO flux measurements at upland and lowland Congo tropical forest site, Tellus B, 53, 220 234, doi:10.1034/j.1600-0889.2001.01237.x, 2001.

Sharkey, T. D., Loreto, F., and Delwiche, C. F.: High-carbon dioxide and sun shade effects on isoprene emission from oak and aspen tree leaves, Plant Cell Environ., 14, 333-338, doi:10.1111/j.1365-3040.1991.tb01509.x, 1991.

Sheil, D., Casson, A., Meijaard, E., van Nordwijk, M., Gaskell, J., Sunderland-Growes, J., Wertz, K., and Kanninen, M.: The impacts and opportunities of oil palm in Southeast Asia: what do we know and what do we need to know?, Occasional paper no. 51, Center for International Forestry Research, Bogor, 2009.

Stanhill, G. and Cohen, S.: Global dimming: a review of the evidence for a widespread and significant reduction in global radiation with discussion of its probable causes and possible agricultural consequences, Agr. Forest Meteorol., 107, 255-278, doi:10.1016/s0168-1923(00)00241-0, 2001.

Staudt, M., Joffre, R., Rambal, S., and Kesselmeier, J.: Effect of elevated $\mathrm{CO}_{2}$ on monoterpene emission of young Quercus ilex trees and its relation to structural and ecophysiological parameters, Tree Physiol., 21, 437-445, 2001.

Takata, K., Emori, S., and Watanabe, T.: Development of the minimal advanced treatments of surface interaction and runoff, Glob. Planet. Change, 38, 209-222, doi:10.1016/s09218181(03)00030-4, 2003.

Tanaka, K., Takizawa, H., Kume, T., Xu, J. Q., Tantasirin, C., and Suzuki, M.: Impact of rooting depth and soil hydraulic properties on the transpiration peak of an evergreen forest in northern Thailand in the late dry season, J. Geophys. Res.-Atmos., 109, D23107, doi:10.1029/2004jd004865, 2004.

Tatebe, H., Ishii, M., Mochizuki, T., Chikamoto, Y., Sakamoto, T., Komuro, Y., Mori, M., Yasunaka, S., Watanabe, M., Oguchi, K., 
Suzuki, T., Nishimura, T., and Kimoto, M.: The initialization of the MIROC climate models with hydrographic data assimilation for decadal prediction, Journal of Meteorogical Society of Japan, 90A, 275-294, 2012.

Tsigaridis, K., Krol, M., Dentener, F. J., Balkanski, Y., Lathière, J., Metzger, S., Hauglustaine, D. A., and Kanakidou, M.: Change in global aerosol composition since preindustrial times, Atmos. Chem. Phys., 6, 5143-5162, doi:10.5194/acp-6-5143-2006, 2006.

Uppala, S. M., Kallberg, P. W., Simmons, A. J., Andrae, U., Bechtold, V. D., Fiorino, M., Gibson, J. K., Haseler, J., Hernandez, A., Kelly, G. A., Li, X., Onogi, K., Saarinen, S., Sokka, N., Allan, R. P., Andersson, E., Arpe, K., Balmaseda, M. A., Beljaars, A. C. M., Van De Berg, L., Bidlot, J., Bormann, N., Caires, S., Chevallier, F., Dethof, A., Dragosavac, M., Fisher, M., Fuentes, M., Hagemann, S., Holm, E., Hoskins, B. J., Isaksen, L., Janssen, P., Jenne, R., McNally, A. P., Mahfouf, J. F., Morcrette, J. J., Rayner, N. A., Saunders, R. W., Simon, P., Sterl, A., Trenberth, K. E., Untch, A., Vasiljevic, D., Viterbo, P., and Woollen, J.: The ERA-40 re-analysis, Q. J. Roy. Meteorol. Soc., 131, 2961-3012, doi:10.1256/qj.04.176, 2005.

Vuorinen, T., Reddy, G. V. P., Nerg, A. M., and Holopainen, J. $\mathrm{K}$.: Monoterpene and herbivore-induced emissions from cabbage plants grown at elevated atmospheric $\mathrm{CO}_{2}$ concentration, Atmos. Environ., 38, 675-682, doi:10.1016/j.atmosenv.2003.10.029, 2004.
Watanabe, M., Suzuki, T., O'Ishi, R., Komuro, Y., Watanabe, S., Emori, S., Takemura, T., Chikira, M., Ogura, T., Sekiguchi, M., Takata, K., Yamazaki, D., Yokohata, T., Nozawa, T., Hasumi, H., Tatebe, H., and Kimoto, M.: Improved Climate Simulation by MIROC5. Mean States, Variability, and Climate Sensitivity, J. Climate, 23, 6312-6335, doi:10.1175/2010jcli3679.1, 2010.

Watanabe, M., Shiogama, H., Yokohata, T., Ogura, T., Yoshimori, M., Emori, S., and Kimoto, M.: Constraints to the tropical lowcloud trends in historical climate simulations, Atmos. Sci. Lett., 12, 288-293, doi:10.1002/asl.337, 2011.

Wilkinson, M. J., Owen, S. M., Possell, M., Hartwell, J., Gould, P., Hall, A., Vickers, C., and Hewitt, C. N.: Circadian control of isoprene emissions from oil palm (Elaeis guineensis), Plant J., 47, 960-968, doi:10.1111/j.1365-313X.2006.02847.x, 2006.

Wilkinson, M. J., Monson, R. K., Trahan, N., Lee, S., Brown, E., Jackson, R. B., Polley, H. W., Fay, P. A., and Fall, R.: Leaf isoprene emission rate as a function of atmospheric $\mathrm{CO}_{2}$ concentration, Glob. Change Biol., 15, 1189-1200, 2008. 